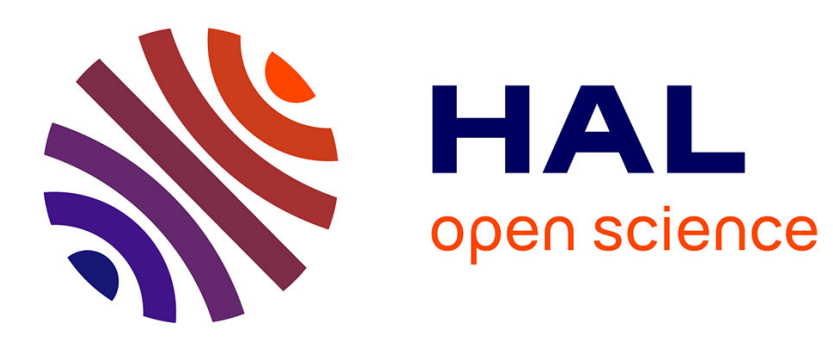

\title{
Frontiers in Anti-Infective Drug Discovery: Volume 9
}

Jean Michel Brunel

\section{To cite this version:}

Jean Michel Brunel (Dir.). Frontiers in Anti-Infective Drug Discovery: Volume 9. BENTHAM SCIENCE PUBLISHERS, 9, 2021, Frontiers in Anti-Infective Drug Discovery, 10.2174/97816810882971210901 . hal-03368297

\section{HAL Id: hal-03368297 \\ https://hal.science/hal-03368297}

Submitted on 11 Oct 2021

HAL is a multi-disciplinary open access archive for the deposit and dissemination of scientific research documents, whether they are published or not. The documents may come from teaching and research institutions in France or abroad, or from public or private research centers.
L'archive ouverte pluridisciplinaire HAL, est destinée au dépôt et à la diffusion de documents scientifiques de niveau recherche, publiés ou non, émanant des établissements d'enseignement et de recherche français ou étrangers, des laboratoires publics ou privés. 


\title{
Scope and limitations on the potent antimicrobial activities of hydrazone derivatives
}

\author{
Jean Michel Brunel*1 \\ Aix Marseille Univ, INSERM, SSA, MCT, Marseille, France.
}

\begin{abstract}
Antimicrobial resistance of Gram-negative bacteria is a major concern and no new classes of antibiotics that are effective against this type of bacteria have been discovered since the 1960s. During the last decades, multiple approaches have been developed to combat such a bacterial resistance. However, the combination of antibiotic resistance mechanisms by bacteria and the limited number of effective antibiotics available, decreases the number of the interventions for the treatment of current bacterial infections. The solution to emerging antibiotic resistance will likely involve new therapies or new classes of antibacterial agents. For a few years now, there was a real interest in the design and synthesis of hydrazones possessing an azometine $\mathrm{NHN}=\mathrm{CH}$ - proton and constituting an important class of compounds for new drugs development as anticonvulsants, antidepressants, antitumoral agents. In this context, the design and antimicrobial evaluation of hydrazone derivatives has constituted one of the new strategies developed to fight bacterial resistance. As pointed out the range of biological activities is very broad, and this review will deal exclusively with the synthesis and use of hydrazones as antimicrobial agents and will not cover the other biological properties already well depicted in literature. Thus, we will report herein the scope and limitation of such an approach providing numerous examples demonstrating structure-activity relationships and potent interesting antimicrobial activities against both fungi, Gram-positive and/or Gram-negative bacteria.
\end{abstract}

Keywords : Hydrazones, Hydrazine, Antimicrobial agents, Gram-positive bacteria, Gram-negative bacteria, Ketones, Aldehydes, Antifungal activity, Azomethine, Antimicrobial resistance, Heterocycles.

\section{INTRODUCTION}

An important interest in the design and synthesis of hydrazones possessing an azometine $-\mathrm{NHN}=\mathrm{CH}$ - proton and constituting an important class of compounds for new drugs development has recently emerged.[1,2] Since the range of biological activities is very broad this review will deal exclusively with the synthesis and use of hydrazones as antimicrobial agents excluding the other well depicted biological properties.[1-7]

Hydrazones, which general formula is $\mathrm{R}-\mathrm{NH}-\mathrm{N}=\mathrm{C}$, have been widely used and studied in organic chemistry. There are easily produced by condensation of a hydrazine $\left(\mathrm{NH}_{2}-\mathrm{NHR}\right)$ with a ketone or an aldehyde (Scheme 1).

\footnotetext{
*Corresponding author Jean Michel Brunel: Aix Marseille Univ, INSERM, SSA, MCT, Marseille, France ; E-mail : bruneljm@yahoo.fr, Tel : (+33) 689271645.
} 


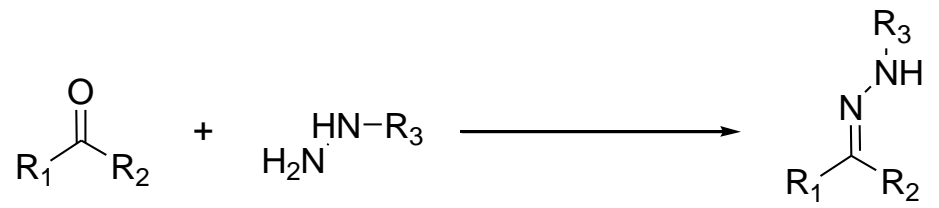

Scheme 1

During numerous decades, this condensation has been the only way of detection of the presence of a ketone or an aldehyde group in a molecule. Moreover, hydrazones have been also involved in many reactions such as:

- The Bamford-Stevens reaction allowing the formation of a dual-link Z (Scheme 2).[8]

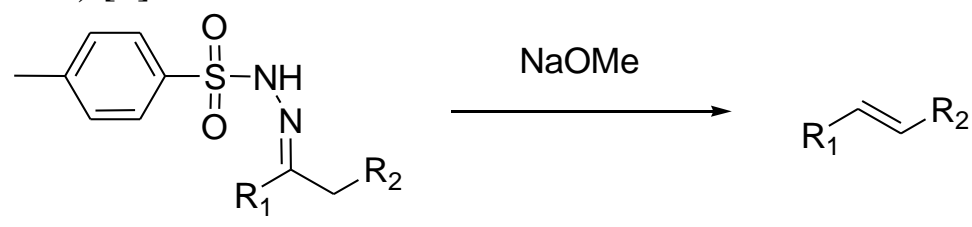

Scheme 2

- The reaction of Shapiro[9] which involves the elimination of a tosylhydrazone group and the formation of a double bond. It is noteworthy that during this reaction the transitional carbanion can be used to graft different functional groups (Scheme 3).

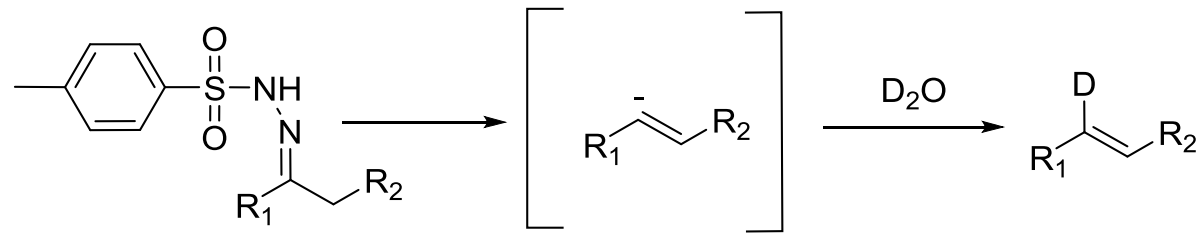

\section{Scheme 3}

Nevertheless, although these hydrazones are well known in organic chemistry, it is only recently that researchers became interested by their biological potentialities particularly for the treatment of infectious diseases.[10]

\section{Hydrazones as potent antimicrobial agents}

As already mentioned, hydrazones possess a general formula $\mathrm{R}-\mathrm{NH}-\mathrm{N}=\mathrm{C}$. In the following part, we will discuss on the antimicrobial activity of different classes of hydrazones depending on the nature of the $\mathrm{R}$ group attached to the nitrogen atom.

\section{1) $R$ is a Hydrogen}

In 2005, Shinge et al. reported the reaction of 4-acetyl-3-arylsydnone derivatives[11] with hydrazine leading to the formation of hydrazones $\mathbf{1}$ and dimers $\mathbf{2}$ in good yields and the evaluation of their antimicrobial activities against various Gram-negative bacteria and fungi (Table 1). 
<smiles>[R]c1ccc(N2NOC(=O)C2/C(C)=N/N)[se]1</smiles>

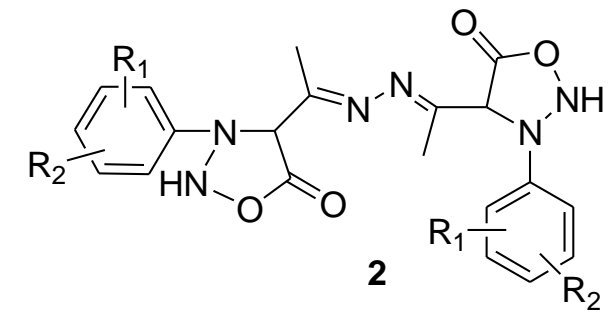

\begin{tabular}{|c|c|c|c|c|c|c|}
\hline \multirow[b]{2}{*}{ Compound } & \multirow[b]{2}{*}{$\mathbf{R}_{1}$} & \multirow[b]{2}{*}{$\mathbf{R}_{\mathbf{2}}$} & \multicolumn{4}{|c|}{ Diameter of inhibition (mm) } \\
\hline & & & $\begin{array}{c}E . \\
\text { coli }\end{array}$ & $\begin{array}{c}P . \\
\text { pyocyanous }\end{array}$ & R. bataticola & $\begin{array}{c}A . \\
\text { niger }\end{array}$ \\
\hline $1 \mathbf{a}$ & $\mathrm{H}$ & $4-\mathrm{Cl}$ & 29 & 24 & 13 & 18 \\
\hline $\mathbf{1 b}$ & $\mathrm{H}$ & $4-\mathrm{Br}$ & 30 & 22 & 14 & 18 \\
\hline 1c & $3-\mathrm{CH}_{3}$ & $4-\mathrm{CH}_{3}$ & 19 & 18 & 18 & 21 \\
\hline 1d & $4-\mathrm{CH}_{3}$ & $3-\mathrm{Cl}$ & 29 & 21 & 12 & 13 \\
\hline 1e & $2-\mathrm{OCH}_{3}$ & $4-\mathrm{Cl}$ & 31 & 26 & 11 & 14 \\
\hline 1f & $4-\mathrm{Cl}$ & $3-\mathrm{F}$ & 29 & 23 & 13 & 16 \\
\hline $2 e$ & $2-\mathrm{OCH}_{3}$ & $4-\mathrm{Cl}$ & 18 & 16 & 11 & 14 \\
\hline $2 f$ & $4-\mathrm{Cl}$ & $3-\mathrm{F}$ & 21 & 15 & 13 & 16 \\
\hline
\end{tabular}

Table 1. Structure and antimicrobial activities of derivatives 1a-2f

Determination of the antifungal activity of derivatives 2 led to similar results that their parent monomers 1 (Table 1, derivatives 1e-1f and 2e-2f) whereas weaker activities were encountered against bacteria. Moreover, compounds possessing a chloro, bromo or fluoro substituent group exhibited antibacterial activities greater than norfloxacin reference drug. Derivative 1c with a methyl group substitution led to an increase of the antifungal activity compared to griseofluvin. Additionally, compound 1d possessing a methyl and halogen substituent, is slightly active against bacteria and less active against fungi compared to reference drugs.

In the same area, Sztanke et al. reported that derivatives 3a-3f presented moderate to good antibacterial activities against both Gram-positive ( $S$. aureus, $S$. epidermidis, S. pyogenes) and Gram-negative bacteria (E. coli) (Table 2).[12] Thus, compound 3d bearing a 1-(4-methoxyphenyl) group appeared to be the most active compound of this series with MICs varying from 15 to $30 \mu \mathrm{M}$ in all cases. Nevertheless, no mechanism of action of such derivatives has still been proposed to rationalize such observations. 


\begin{tabular}{|c|c|c|c|c|c|c|}
\hline & \multicolumn{6}{|c|}{$\mathrm{MIC}(\mu \mathrm{M})$} \\
\hline$\stackrel{\mathrm{H}}{\mathrm{N}} \mathrm{NH}_{2}$ & $3 \mathbf{a}$ & $3 \mathbf{b}$ & $3 c$ & 3d & $3 \mathbf{e}$ & 3f \\
\hline $\boldsymbol{R}$ & $\mathrm{H}$ & $2-\mathrm{CH}_{3}$ & $2-\mathrm{OCH}_{3}$ & $4-\mathrm{OCH}_{3}$ & $2,3-\mathrm{CH}_{3}$ & $4-\mathrm{Cl}$ \\
\hline S. aureus & 41.1 & 39.3 & 37.4 & 29.9 & 37.6 & 29.5 \\
\hline S. epidermidis & 41.1 & 31.4 & 37.4 & 18.7 & 18.8 & 18.4 \\
\hline S. pyogenes & 65.8 & 78.6 & 74.8 & 59.8 & 75.2 & 59.1 \\
\hline E. coli & 41.1 & 15.7 & 29.9 & 15.0 & 18.8 & 36.9 \\
\hline
\end{tabular}

Table 2. Antimicrobial activities of derivatives 3a-f

\section{2) $\mathbf{R}$ is an aryl group}

Most of the results presented in this part have been reported in the last twenty years demonstrating the interest and potentiality of such compounds. In 2002, Moreau et al. carried out the synthesis of new polyaromatic molecules $\mathbf{4 a - 4 b}$ and have evaluated their antifungal properties against $C$. albicans and $C$. krusei strains.[13] Nevertheless, the results remain quite modest in terms of diversity with respect to the number and nature of the strains tested (Table 3 ).<smiles>[X]c1c(O)c([X])c2oc3c(C=N)cccc3c(=O)c2c1O</smiles>

4a: $X=H ; R^{\prime}=F$

4b: $\mathrm{X}=\mathrm{Cl} ; \mathrm{R}^{\prime}=\mathrm{F}$<smiles>CNc1ccccc1</smiles>

\begin{tabular}{c|cc}
\cline { 2 - 3 } & \multicolumn{2}{|c}{ Inhibition diameter (mm) } \\
\hline Compounds & C. krusei & C. albicans \\
\hline 4a & 15 & 10 \\
4b & 35 & 15 \\
\hline
\end{tabular}

Table 3. Structure and biological activities of compounds 4

In the same context, Tyrkov et al. demonstrated that a double substitution at the nitrogen atom by two phenyl groups lead to molecules 5a-5c possessing significant activities against Gram-positive bacteria such as $S$. aureus and $S$. pneumoniae as well as against Gram-negative E. coli and P. aeruginosa (Table 4).[14] 


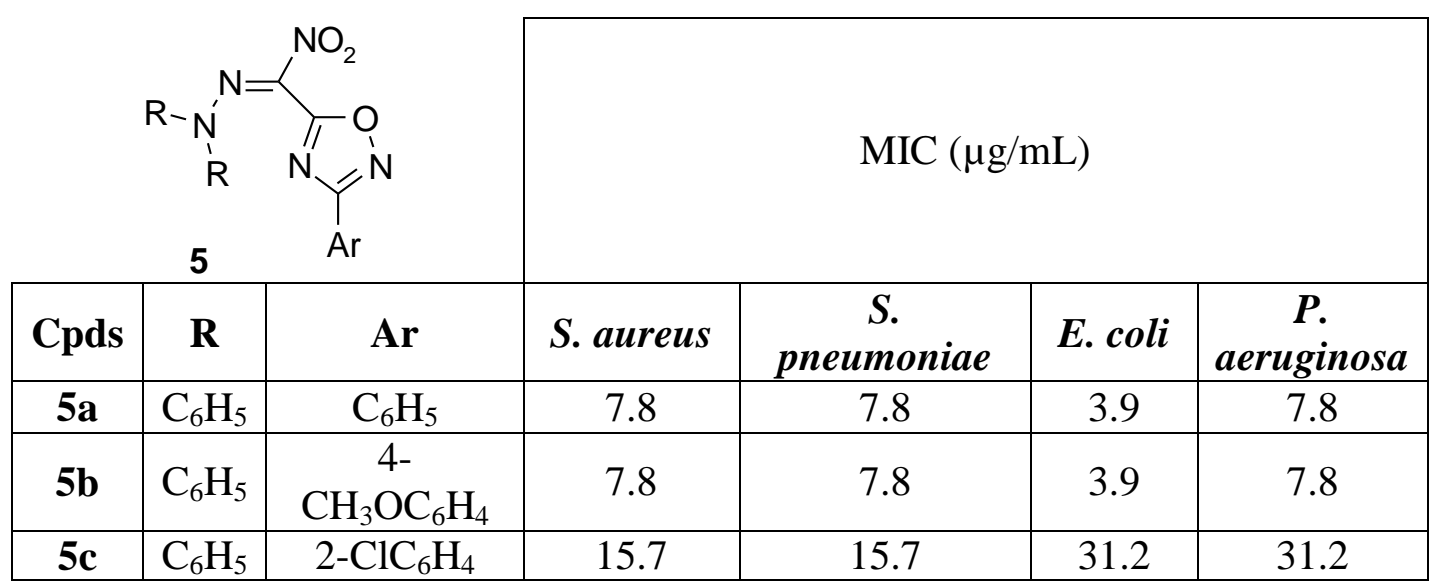

Table 4. Antimicrobial activities of compounds 5a-5c

Some other compounds of interest were reported including derivatives $\mathbf{6 a - 6 c}, 7 \mathbf{a}-$ $\mathbf{7 b}$ and 8a-8b and demonstrating moderate to good biological activities (Scheme 4).[15-17] Particularly, molecules $\mathbf{7}$ and $\mathbf{8}$ present anti Trichophyton mentagrophytes and Microsporum gyptem activities with MIC less than 10 $\mu \mathrm{g} / \mathrm{mL}$.[15] On the other hand, some of them possessing fluorine groups can inhibit the growth of Mycobacterium tuberculosis at a concentration of 3.12 $\mu \mathrm{g} / \mathrm{mL} .[17]$

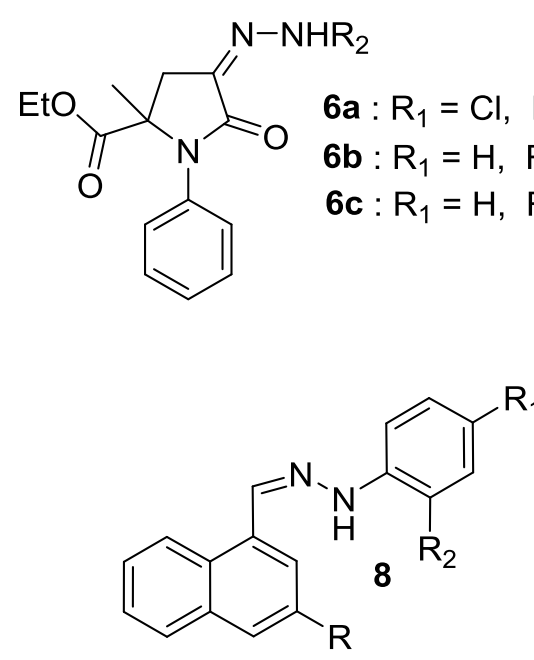<smiles></smiles>

\section{3) $\mathbf{R}$ is a heterocyclic ring}

In 2001, Oliveira et al. reported that hydrazones structurally more complex possess specific antimicrobial activities. 


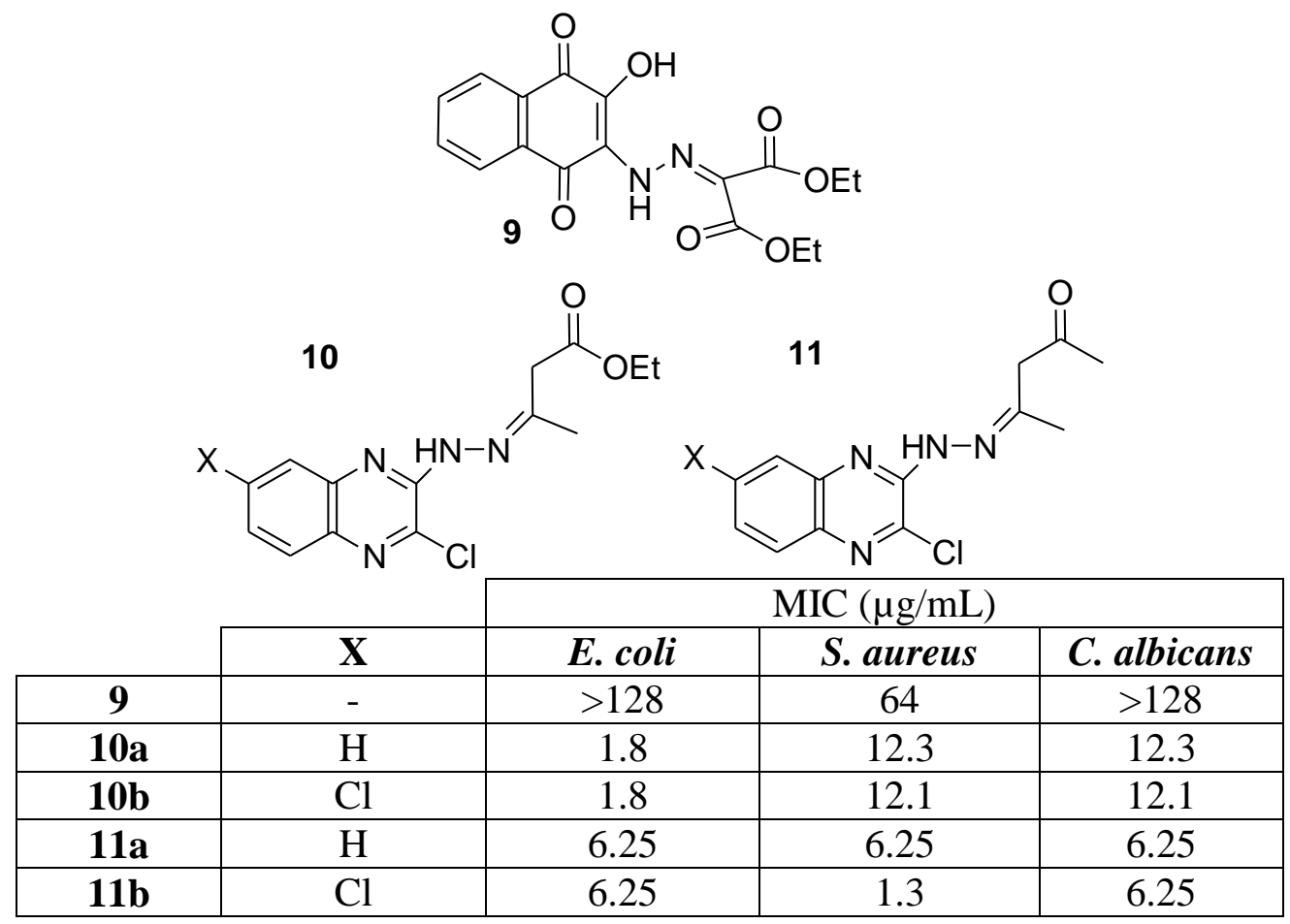

Table 5. Antimicrobial activities of compounds 10-11.

Thus, compound 9 can act against different strains of Gram-positive $S$. aureus sensitive or resistant to methicillin but with MICs ranging from 64 to 128 $\mu \mathrm{g} / \mathrm{mL}$.[18] On the other hand, molecules 10a, 10b and 11a, 11b present a wider spectrum of activity against both Gram-negative, Gram-positive bacteria as well as fungi (Table 5).[19] It is also noteworthy that the replacement of a hydrogen group by a chlorine one lead to an increase in terms of activity of $\mathbf{1 1 b}$ against $S$. aureus with a MIC of $1.3 \mu \mathrm{g} / \mathrm{mL}$.

In another study, Savini et al. have described the design of quinolyl hydrazone derivatives 12a-c and 13a-b presenting modest activities against B. cereus, A. fumigatus and C. albicans with MICs up to $100 \mu \mathrm{g} / \mathrm{mL}$.[20]

\begin{tabular}{|c|c|}
\hline Compound & Het \\
\hline 12a & 4-Methyl-2-quinolyl \\
\hline 12b & 4,6-Dimethyl-2-quinolyl \\
\hline 12c & 4-Methyl-7-methoxy-2-quinolyl \\
\hline 13a & 4-Methyl-2-quinolyl \\
\hline 13b & 4,6-Dimethyl-2-quinolyl \\
\hline
\end{tabular}<smiles>CCCCCC1CCN=C1N/N=C/c1ccc(C)s1</smiles>

Table 6. Structure of derivatives 12-13 
Additionally, 2-arylhydrazono-3-oxobutyrates 14 (Table 6) presented antibacterial activities against Gram-positive bacteria $S$. aureus with a MIC value of $7.8 \mu \mathrm{g} / \mathrm{mL}$ whereas moderate ones (MICS ranging from 100 to $250 \mu \mathrm{g} / \mathrm{mL}$ ) were encountered against Gram-negative bacteria and yeasts.[21] Surprisingly, arylhydrazone derivatives 15 and 16 possess MICs varying from 0.78 to $6.25 \mu \mathrm{g} / \mathrm{mL}$ against $M$. tuberculosis and present a low cytotoxicity $\left(120<\mathrm{IC}_{50}(\mu \mathrm{g} / \mathrm{mL})<180\right)$ suggesting a potent development for a human therapeutic use.[22]

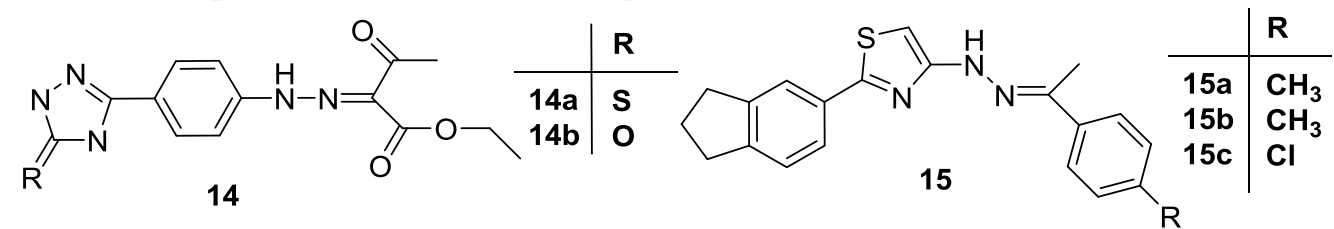

\begin{tabular}{|c|c|c|c|c|}
\hline$\overbrace{16}^{\mathrm{HN}^{-\mathrm{N}}={ }_{\mathrm{Ar}}}$ & $\mathbf{R}$ & $\mathbf{R}^{\prime}$ & Ar & $\begin{array}{c}\text { M. } \\
\text { tuberculosis } \\
\text { MIC }(\mu \mathrm{g} / \mathrm{mL})\end{array}$ \\
\hline $16 a$ & $\mathrm{H}$ & $7-\mathrm{OCH}_{3}$ & \multirow{5}{*}{$\begin{array}{l}\text { 4-OCH} 3^{-} \\
\text {naphthyl }\end{array}$} & 0.78 \\
\hline $16 b$ & \multirow{4}{*}{$\mathrm{CH}_{3}$} & $8-\mathrm{OCH}_{3}$ & & 1.56 \\
\hline $16 \mathrm{c}$ & & $7-\mathrm{OC}_{2} \mathrm{H}_{5}$ & & 1.56 \\
\hline 16d & & $6-\mathrm{n}-\mathrm{OC}_{4} \mathrm{H}_{9}$ & & 0.78 \\
\hline $16 \mathrm{e}$ & & $7-\mathrm{Cl}$ & & 0.78 \\
\hline
\end{tabular}

Table 6. Structure of derivatives 14-15 and antituberculosis activities of compounds 16a-16e.

Another series of heterocyclic derivatives 17-18 were reported by Shaban[23] and El-Gazzar[24] demonstrating moderate activities against $C$. albicans and $C$. glabrata with diameter of inhibition of $8 \mathrm{~mm}$. On the other hand, compound $\mathbf{1 8}$ appears highly active against bacteria such as $S$. aureus $(16 \mathrm{~mm})$, or Gramnegative bacteria $P$. aeruginosa $(14 \mathrm{~mm})$, E. coli $(15 \mathrm{~mm})$ or $K$. pneumoniae $(18$ $\mathrm{mm})$.<smiles>[R]C=NNc1nnc2c3ccccc3n(C)c2n1</smiles>

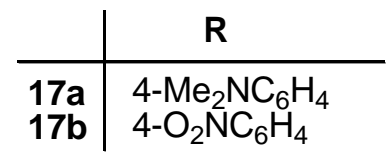<smiles>O=c1[nH]c(N/N=C/c2ccccc2)nc2nc3c(c(-c4ccccc4)c12)CCCC3</smiles>

Scheme 5 
In the same context, Nassar et al. reported that uracil derivatives possess potent antimicrobial activities as illustrated by derivatives 19-21 easily prepared as outlined in Table 7.[25] The different compounds presented antibacterial activities against L. monocytogenes and were more potent than the reference drugs. Moreover, antibacterial activity of $\mathbf{1 9}$ was significant against Gram-negative bacteria $E$. coli, with an inhibition zone of $13 \mathrm{~mm}$ compared to cefoperazone.<smiles>[R]c1nc(NN)[nH]c(=O)c1C#N</smiles>

\begin{tabular}{|c|c|c|c|c|}
\hline \multirow{2}{*}{ Bacteria } & \multicolumn{4}{|c|}{ Zone of inhibition $(\mathrm{mm})$ antibacterial activity $(1 \mathrm{mg} / \mathrm{mL})$} \\
\cline { 2 - 5 } & $\mathbf{1 9}$ & $\mathbf{2 0}$ & $\mathbf{2 1}$ & Cefoperazone \\
\hline S. aureus & 8 & 7.5 & 7.5 & 12 \\
\hline L. monocytogenes & 14 & 12 & 12 & 11 \\
\hline E. coli & 13 & 9 & 8.5 & 15 \\
\hline Y. enterolitica & - & 9 & - & 12 \\
\hline
\end{tabular}

Table 7. Structure and antibacterial activities of derivatives 19-21

Recently, quinoxaline derivatives were synthesized by the reaction of $o$ phenylenediamine with oxalic acid to yield 1,4-dihydro quinoxaline-2,3-dione and then treatment with thionyl chloride to yield 2,3-dichloro quinoxaline. This was further treated with hydrazine hydrate to produce 2,3-dihydrazinyl quinoxaline which reacted subsequently with the substituted aromatic aldehyde to afford 2,3bis(2-(substituted benzylidine) hydrazinyl)quinoxaline 22 (Scheme 6).

\begin{tabular}{|c|c|c|c|c|c|}
\hline $\begin{array}{c}\mathbf{2 2 a} \\
\mathrm{R}=4 \mathrm{FC}_{6} \mathrm{H}_{4}\end{array}$ & $\begin{array}{c}\mathbf{2 2 c} \\
\mathrm{R}=3 \mathrm{ClC}_{6} \mathrm{H}_{4}\end{array}$ & $\begin{array}{c}\mathbf{2 2 e} \\
\mathrm{R}= \\
4 \mathrm{OMeC}_{6} \mathrm{H}_{4}\end{array}$ & $\begin{array}{c}\mathbf{2 2 g} \\
\mathrm{R}=3,4,5 \\
(\mathrm{OMe})_{3} \mathrm{C}_{6} \mathrm{H}_{2}\end{array}$ & $\begin{array}{c}\mathbf{2 2 i} \\
\mathrm{R}=4 \mathrm{NO}_{2} \mathrm{C}_{6} \mathrm{H}_{4}\end{array}$ & $\begin{array}{c}\mathbf{2 2 k} \\
\mathrm{R}=4 \mathrm{OH} 3 \mathrm{OMeC}_{6} \mathrm{H}_{3}\end{array}$ \\
\hline $\begin{array}{c}\mathbf{2 2 b} \\
\mathrm{R}=2 \mathrm{ClC}_{6} \mathrm{H}_{4}\end{array}$ & $\begin{array}{c}\mathbf{2 2 d} \\
\mathrm{R}=4 \mathrm{ClC}_{6} \mathrm{H}_{4}\end{array}$ & $\begin{array}{c}\mathbf{2 2 f} \\
\mathrm{R}=3,4 \\
(\mathrm{OMe})_{2} \mathrm{C}_{6} \mathrm{H}_{3}\end{array}$ & $\begin{array}{c}\mathbf{2 2 h} \\
\mathrm{R}=2 \\
\mathrm{NO}_{2} \mathrm{C}_{6} \mathrm{H}_{4}\end{array}$ & $\begin{array}{c}\mathbf{2 2 j} \\
\mathrm{R}=\mathrm{C}_{6} \mathrm{H}_{5}\end{array}$ & $\begin{array}{c}\mathbf{2 2 l} \\
\mathrm{R}=2 \mathrm{OHC}_{6} \mathrm{H}_{4}\end{array}$ \\
\hline
\end{tabular}

Scheme 6. Structure of the different quinoline derivatives 22a-22l 
The Gram-positive and Gram-negative bacteria are sensitive to most of the tested compounds, and particularly 22c, 22d, and 22i presenting significant activities against both type of microbial strains than others. Whereas the compound substituted with an electron donating group or unsubstituted the phenyl ring offered a low to moderate activity against selected strains, derivatives bearing a methoxy group as a substituent of the phenyl ring undergo the least effect against selected bacterial strains (Table 8).[26]

\begin{tabular}{|c|c|c|c|c|}
\hline \multirow{2}{*}{ Compounds } & \multicolumn{2}{|c|}{ Gram-positive bacteria } & \multicolumn{2}{c|}{ Gram-negative bacteria } \\
\cline { 2 - 5 } & S. pyogenes & S. aureus & E. coli & P. aeruginosa \\
\hline $\mathbf{2 2 a}$ & 1.1 & 1.28 & 1.89 & 1.97 \\
\hline $\mathbf{2 2 b}$ & 1.09 & 1.12 & 1.37 & 1.84 \\
\hline $\mathbf{2 2 c}$ & 0.97 & 0.92 & 0.93 & 0.98 \\
\hline $\mathbf{2 2 d}$ & 1.01 & 1.03 & 0.96 & 1.02 \\
\hline $\mathbf{2 2 e}$ & 2.87 & 3.28 & 3.17 & 3.14 \\
\hline $\mathbf{2 2 f}$ & 2.97 & 3.31 & 2.97 & 3.48 \\
\hline $\mathbf{2 2 g}$ & 3.03 & 3.43 & 3.23 & 3.17 \\
\hline $\mathbf{2 2}$ & 2.14 & 1.98 & 1.87 & 2.73 \\
\hline $\mathbf{2 2} \mathbf{2}$ & 1.04 & 1.06 & 1.10 & 1.01 \\
\hline $\mathbf{2 2 j}$ & 2.89 & 2.91 & 2.76 & 3.01 \\
\hline $\mathbf{2 2 k}$ & 1.87 & 2.12 & 2.28 & 1.98 \\
\hline $\mathbf{2 2 l}$ & 1.97 & 2.08 & 1.83 & 1.79 \\
\hline Ciprofloxacine & 0.97 & 0.89 & 0.93 & 0.96 \\
\hline
\end{tabular}

Table 8. Antimicrobial activities of quinoline derivatives expressed as MIC $(\mathrm{mg} / \mathrm{mL})$

Another study dealing with the synthesis of benzenesulfonylurea and thiourea derivatives of $2 \mathrm{H}$ - pyran and $2 \mathrm{H}$ - pyridine- 2- ones as antibacterial agents needs also to be mentioned. The results revealed that most of the tested compounds displayed greater inhibitory effect on the growth of the tested Gram-positive strain compared to Gram-negative ones such as $P$. aeruginosa. Moreover, few compounds were able to exert a potent antifungal activity against $C$. albicans, while all the tested compounds lacked antifungal activity against the Aspergillus niger fungus. A close examination of the structures of the active compounds revealed that the antimicrobial profile of the pyridine- 2- one compounds seemed to be more interesting than their corresponding pyran- 2- one isosteres, as evidenced by their MIC values (Table 9).[27] 
<smiles>C/C(=N\Nc1ccccc1)c1c(O)cc(C)n(NC(=O)NC2CCCCC2)c1=O</smiles><smiles>C/C(=N/Nc1ccc(S(=O)(=O)Nc2ccccc2)cc1)c1c(O)cc(C)n(NC(N)=O)c1=O</smiles>

\begin{tabular}{|c|c|c|c|c|}
\hline \multirow{2}{*}{ Compounds } & \multicolumn{2}{|c|}{ Gram-positive bacteria } & \multicolumn{2}{c|}{ Gram-negative bacteria } \\
\cline { 2 - 5 } & B. subtilis & S. aureus & E. coli & P. aeruginosa \\
\hline 23a & 100 & 50 & $>200$ & $>200$ \\
\hline 23b & 50 & 50 & 200 & $>200$ \\
\hline 23c & $>200$ & $>200$ & $>200$ & $>200$ \\
\hline 23d & 50 & 12.5 & 50 & 200 \\
\hline ampicillin & 25 & 12.5 & 25 & 50 \\
\hline
\end{tabular}

Table 9. Minimum Inhibitory Concentrations $(\mu \mathrm{g} / \mathrm{mL})$ of compounds 23a-23d

Introduction of an amino group at position 1 of the pyridine ring as in compound 23b resulted in significant changes of the overall antimicrobial spectrum. It showed two- fold improvement in the potency against $B$. subtilis when compared with 23a (MIC 50 vs $100 \mu \mathrm{g} / \mathrm{mL}$, respectively) whereas it revealed moderate activity against E. coli (MIC $200 \mu \mathrm{g} / \mathrm{mL}$ ). Furthermore, compound 23d produced the most potent antimicrobial activity in the current series of compounds (more potent than ampicillin (MIC $12.5 \mu \mathrm{g} / \mathrm{mL}$ )) against $S$. aureus, whereas its activity against $B$. subtilis and $E$. coli was $50 \%$ lower than that observed for ampicillin (MIC 50 vs $25 \mu \mathrm{g} / \mathrm{mL}$, respectively).

Even if numerous of them presented a weak interest in terms of encountered biological activities, it is of interest to report the design of peculiar hydrazone compounds that we can find in literature. Thus, the synthesis and evaluation of antimicrobial activities of compounds 24-25 was achieved demonstrating low activities against both Gram-positive and Gram-negative bacteria (Table 10).[28] 


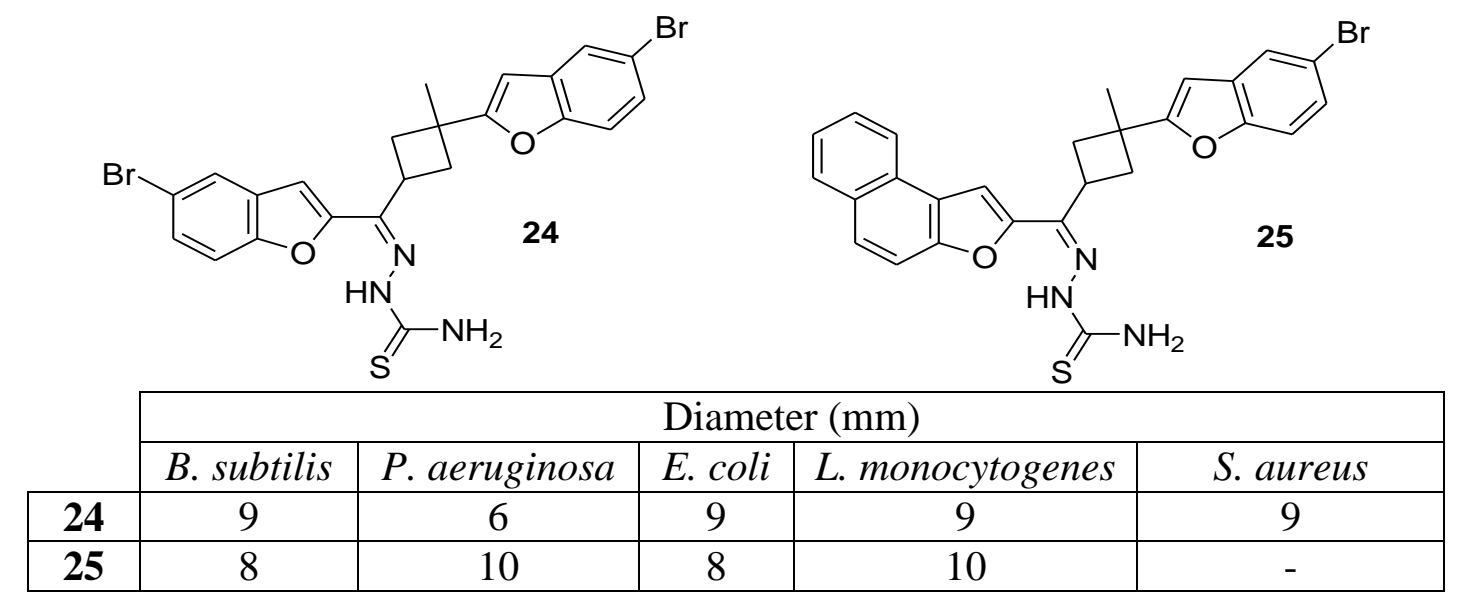

Table 10. Antimicrobial activities of hydrazones 24-25

More recently, steroid hydrazone derivatives 26-28 were designed and tested against various bacteria. The results indicated that compound 26a-26b[29] are only active against $E$. coli whereas derivatives 27-28[30] presented MICs ranging from 32 to $128 \mu \mathrm{g} / \mathrm{mL}$ against both Gram-positive and Gram-negative bacteria (Table $11)$.<smiles>[R]C1CC[C@]2(C)C(=CC(=NNC(N)=S)C3CCC([C@H](C)CCCC(C)C)C32C)C1</smiles><smiles>[R]C1CC[C@]2(C)C(=CC(=NNC(=S)NC3CCCC3)C3CCC4C(C)CCCC(C)C4CCC32C)C1</smiles>

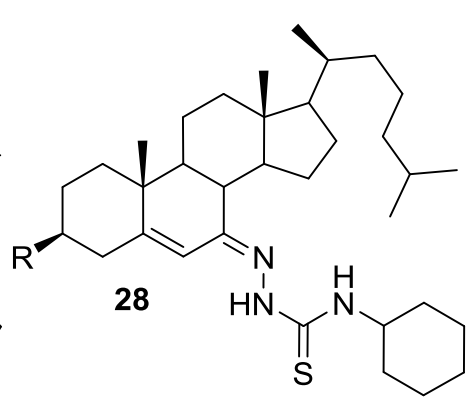

\begin{tabular}{|c|c|c|c|c|c|c|}
\hline & \multicolumn{6}{|c|}{ MIC $(\mu \mathrm{g} / \mathrm{mL})$} \\
\hline & $26 a$ & $26 \mathrm{~b}$ & $27 \mathbf{a}$ & $27 b$ & $28 \mathbf{a}$ & $28 b$ \\
\hline $\mathbf{R}$ & $\mathrm{CH}_{3} \mathrm{COO}$ & $\mathrm{Cl}$ & OAc & $\mathrm{Cl}$ & OAc & $\mathrm{Cl}$ \\
\hline S. aureus & - & - & 32 & 64 & 64 & 32 \\
\hline S. pyogenes & - & - & 64 & 64 & 64 & 64 \\
\hline S. typhimurium & - & - & 64 & 128 & 64 & 128 \\
\hline E. coli & 128 & 64 & 32 & 64 & 32 & 64 \\
\hline
\end{tabular}

Table 11. Antimicrobial activities of hydrazones 26-28

In 2008, new promising hydrazone anti-tuberculosis agents (29-30) were described in literature (Scheme 6). Thus, compounds 29 and $\mathbf{3 0}$ present MICs of $6.25 \mu \mathrm{g} / \mathrm{mL}$ against $M$. tuberculosis.[31] Furthermore, 30d can inhibit the growth of this microorganism by 79\%.[32] Nevertheless, no more results dealing the mechanism of action or improvement of the design of such derivatives were reported until now. 
<smiles>O=C1/C(=N\NC(=S)NC2CCCCC2)c2cc([N+](=O)[O-])ccc2N1CN1CCOCC1</smiles><smiles>[R2]NC(=S)Nc1ccc(OCc2n[nH]c(=S)n2[R1])cc1</smiles>

\begin{tabular}{l|l|l} 
& \multicolumn{1}{|c|}{$\mathbf{R}_{\mathbf{1}}$} & \multicolumn{1}{c}{$\mathbf{R}_{\mathbf{2}}$} \\
\hline $\mathbf{3 0 a}$ & $\mathrm{CH}_{3}$ & $\mathrm{C}_{6} \mathrm{H}_{5}$ \\
$\mathbf{3 0 b}$ & $\mathrm{C}_{2} \mathrm{H}_{5}$ & $\mathrm{CH}_{2} \mathrm{CH}=\mathrm{CH}_{2}$ \\
$\mathbf{3 0 c}$ & $\mathrm{CH}_{3}$ & $\mathrm{C}_{6} \mathrm{H}_{5}$ \\
$\mathbf{3 0 d}$ & $\mathrm{CH}_{2} \mathrm{CH}=\mathrm{CH}_{2}$ &
\end{tabular}

\section{Scheme 6}

In 2012, Karaca et al. reported the synthesis of compounds which contain hydrazone bridged thiazole and pyrrole rings easily obtained by directly reacting pyrrole-2-carboxaldehydes with thiosemicarbazide in ethanol and subsequently condensed them with $\alpha$-bromoacetophenone derivatives (Hantzsch reaction) to afford 1-substituted pyrrole-2-carboxaldehyde [4-(4-substituted phenyl)-1,3thiazol-2-yl] hydrazones in good isolated yields (Scheme 7).[33] All the compounds were screened for their antibacterial and antifungal activities against twelve different bacteria, but they only showed good activity against $S$. aureus and E. faecalis with MICs ranging from 6.25 to $25 \mu \mathrm{g} / \mathrm{mL}$.

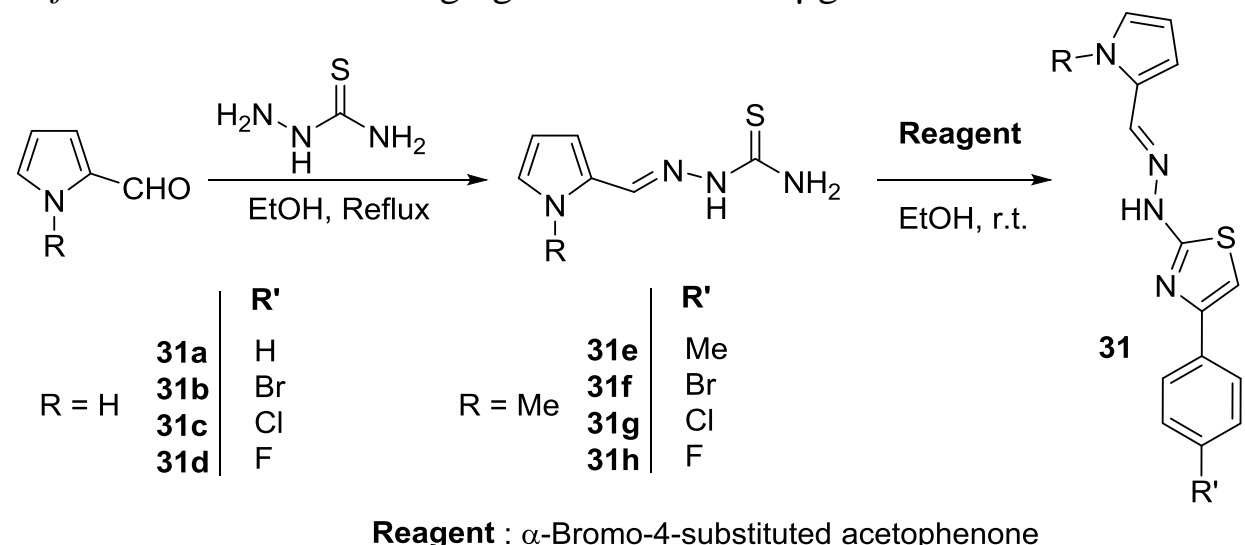

\section{Scheme 7}

Derivatives of 3-pyrazolylquinolinone, in three different types; enaminones 32, enones 33, and hydrazonones 34, have been also investigated for their in vitro antimicrobial activity (Scheme 8).[34, 35]<smiles>[R]N/C=C1/C(=O)NN=C1c1c(O)c2ccccc2n(C)c1=O</smiles><smiles>[R]C=C1C(=O)NN=C1c1c(O)c2ccccc2n(C)c1=O</smiles><smiles>[R]NN=C1C(=O)NN=C1c1c(O)c2ccccc2n(C)c1=O</smiles>

Scheme 8 
The compounds were screened for their biological activities and revealed that hydrazonones 34 possess desirable antimicrobial activity against both bacteria and fungi groups tested.

Recently, novel series of 4,6-disubstituted-1,3,5-triazines containing hydrazone derivatives 35-36 as well as fluorenyl-hydrazonothiazoles 37-38 were synthesized employing ultrasonic irradiation and conventional heating. The ultrasonication gave the target products in higher yields and purity in shorter reaction times compared with the conventional method.[36, 37]

The biological results indicated that only compounds 35 and 36 displayed moderate biological activity against Gram-positive and Gram-negative bacteria, while fluorenyl-hydrazonothiazoles 37-38 present interesting antifungal activities (Table 12).<smiles>COc1nc(N/N=C/c2ccccn2)nc(OC)n1</smiles><smiles>Clc1ccc(/C=N/Nc2nc(N3CCOCC3)nc(N3CCOCC3)n2)cc1</smiles>

\begin{tabular}{|c|c|c|c|c|c|c|c|c|}
\hline \\
\hline S. aureus & 100 & 100 & 50 & 25 & 25 & 12.5 & 25 & 12.5 \\
\hline B. laterosporus & 50 & 50 & $\mathrm{NT}$ & $\mathrm{NT}$ & $\mathrm{NT}$ & $\mathrm{NT}$ & $\mathrm{NT}$ & $\mathrm{NT}$ \\
\hline E. coli & $\mathrm{NA}$ & $\mathrm{NA}$ & 50 & 6.25 & 25 & 25 & 25 & 12.5 \\
\hline P. aeruginosa & $\mathrm{NA}$ & $\mathrm{NA}$ & 25 & 25 & 25 & 12.5 & 12.5 & 25 \\
\hline A. niger & $\mathrm{NA}$ & $\mathrm{NA}$ & 25 & 12.5 & 12.5 & 12.5 & 12.5 & 12.5 \\
\hline C. albicans & $\mathrm{NA}$ & $\mathrm{NA}$ & 25 & 12.5 & 25 & 50 & 50 & 50 \\
\hline
\end{tabular}

Table 12. Antimicrobial activities of hydrazones 35-38

More recently, Chellamella et al. reported the synthesis and biological evaluation as antimicrobial agents of ethyl-2-(3-((2-(4-(4-aryl)thiazol-2yl)hydrazono)methyl)-4-hydroxy/isobutoxyphenyl)-4-methylthiazole-5carboxylate compounds (39a-f and 40a-f) by employing a one-pot multi- 
component approach. The overall activity data revealed that the presence of a coumarin motif in their structure is essential for the broad-spectrum antimicrobial activity. These compounds could bind the active site of the enzyme, DNA gyrase which is responsible for the bacterial replication and thus lead to the inhibition of the bacterial growth (Table 13).[38]<smiles>CCOC(=O)c1cnc(-c2ccc(O)c(C=O)c2)s1</smiles><smiles>NC(=S)NN[14CH2][14CH2]C(=O)CBr</smiles>

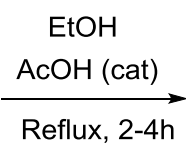<smiles>[R7]Oc1ccc(-c2ncc(C(=O)OCC)s2)cc1/C=N/Nc1nc(I)cs1</smiles>

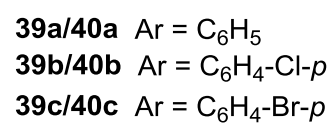

39e/40e $\mathrm{Ar}=$ Coumarin $-3-\mathrm{yl}$

39f/40f $\mathrm{Ar}=$ Benzo[f]coumarin-3-yl

39a-f $R=H$

40a-f $R=$ Isobutyl

\begin{tabular}{c|c|c|c|c|c}
\hline & \multicolumn{5}{|c}{ MIC $(\boldsymbol{\mu g} / \mathbf{m L})$} \\
\cline { 2 - 6 } & S. aureus & B. subtilis & $\boldsymbol{E}$. coli & C. albicans & A. niger \\
\hline 39a & 40 & 35 & 35 & 25 & 35 \\
39b & 35 & 30 & 25 & 25 & 50 \\
39c & 35 & 30 & 50 & 75 & 50 \\
39d & 40 & 30 & 50 & 50 & 25 \\
39e & $\mathbf{1 5}$ & $\mathbf{2 0}$ & $\mathbf{2 0}$ & $\mathbf{1 2 . 5}$ & $\mathbf{1 2 . 5}$ \\
39f & $\mathbf{1 5}$ & $\mathbf{2 5}$ & $\mathbf{2 0}$ & $\mathbf{1 2 . 5}$ & $\mathbf{1 2 . 5}$ \\
40a & 30 & 30 & 35 & 75 & 100 \\
40b & 25 & 25 & 20 & 75 & 75 \\
40c & 35 & 30 & 35 & 50 & 75 \\
40d & 25 & 25 & 30 & 75 & 75 \\
40e & $\mathbf{1 5}$ & $\mathbf{1 5}$ & $\mathbf{2 0}$ & $\mathbf{1 2 . 5}$ & $\mathbf{2 5}$ \\
40f & $\mathbf{2 0}$ & $\mathbf{2 0}$ & $\mathbf{2 0}$ & $\mathbf{1 2 . 5}$ & $\mathbf{1 2 . 5}$ \\
\hline
\end{tabular}

Table 13. Structure and antimicrobial activities of derivatives 39-40

\section{4) Sulfonylhydrazones}

Sulfonylhydrazones are hydrazones presenting the general formula: $\mathrm{R}_{1} \mathrm{R}_{2} \mathrm{C}=\mathrm{N}$ $\mathrm{NH}-\mathrm{SO}_{2}-\mathrm{R}_{3}$.

In 1984, Bhatt et al. have prepared the molecules 41a and 41b possessing antibacterial activity against $S$. aureus (inhibition diameter: $40 \mathrm{~mm}$ ) and E. coli (30mm), respectively.[39] In the same context, Salama et al. designed analogues of these molecules demonstrating the influence of the structure on their antimicrobial activities.[40] Thus, compounds $\mathbf{4 2 a - 4 2 b}$ were identified as the best analogues active both against Gram-positive or negative bacteria and fungi (Scheme 9). 


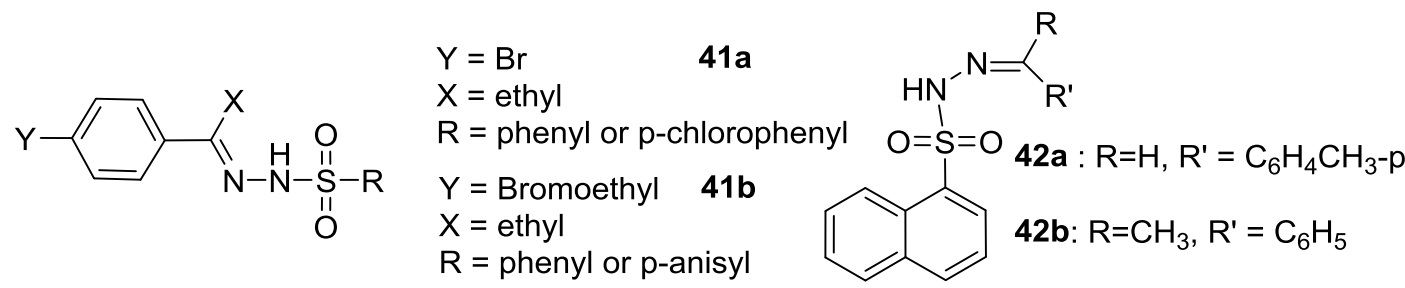<smiles>[R]/C(=N\NS([R])(=O)=O)c1cc(O)cc(Br)c1O</smiles>

43a R $=\mathrm{C}_{6} \mathrm{H}_{4}\left(\mathrm{CH}_{2}\right)_{2} \mathrm{COOH} \quad \mathrm{R}^{\prime}=\mathrm{CH}_{3}$
43b R $=\mathrm{C}_{6} \mathrm{H}_{4}\left(\mathrm{CH}_{2}\right)_{2} \mathrm{COOOH} \mathrm{R}^{\prime}=\mathrm{C}_{6} \mathrm{H}_{5}$

Scheme 9

On the other hand, the group of Shad reported the synthesis of hydrazones 43a43b active against $E$. coli and $S$. aureus with a diameter of inhibition of 29 and 27 $\mathrm{mm}$, respectively. Furthermore, they are less active against $B$. negaterium with only a $12 \mathrm{~mm}$ diameter of inhibition encountered (Scheme 9).[41]

In 2004, The first cholesteryl hydrazone derivatives 44-45 were synthesized and tested for their antimicrobial activities demonstrating interesting antifungal activities especially against $C$. albicans with MICs ranging from 1.25 and 25 $\mu \mathrm{g} / \mathrm{mL}$ (Scheme 10).[42] Recently, antiviral activities of hydrazones of $5 \alpha$ steroids were reported highlighting the potent interest of such derivatives against polio, Rift Valley fever, and influenza A viruses.[43]<smiles>[R7]C(C)[C@H]1CCC2C3C/C(=N/NP)C4C[C@@H](O)CC[C@]4(C)C3CC[C@]21C</smiles>

44

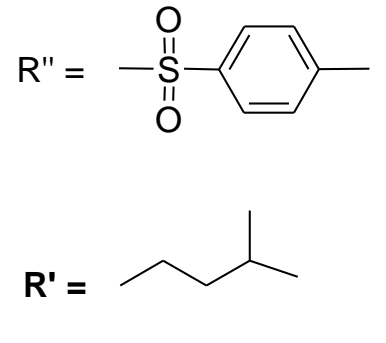

Scheme 10<smiles>[R7]C(C)[C@H]1CCC2C3C(=NN[PH])C=C4C[C@@H](O)CC[C@]4(C)C3CC[C@]21C</smiles>

\section{5) Ylidene hydrazide derivatives}

Another class of hydrazones is constituted by ylidene hydrazide derivatives 46 possessing a hydrazone function and an amide group as illustrated in Scheme 11 and where R, R' and R" could pertain to linear or cyclic alkyl or aryl substituents. 


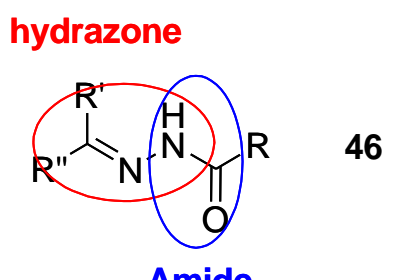

Amide

Scheme 11.

Metwally et al. reported the synthesis of derivatives 47 from quinoline and bearing various substituent groups (Table 14).[44]

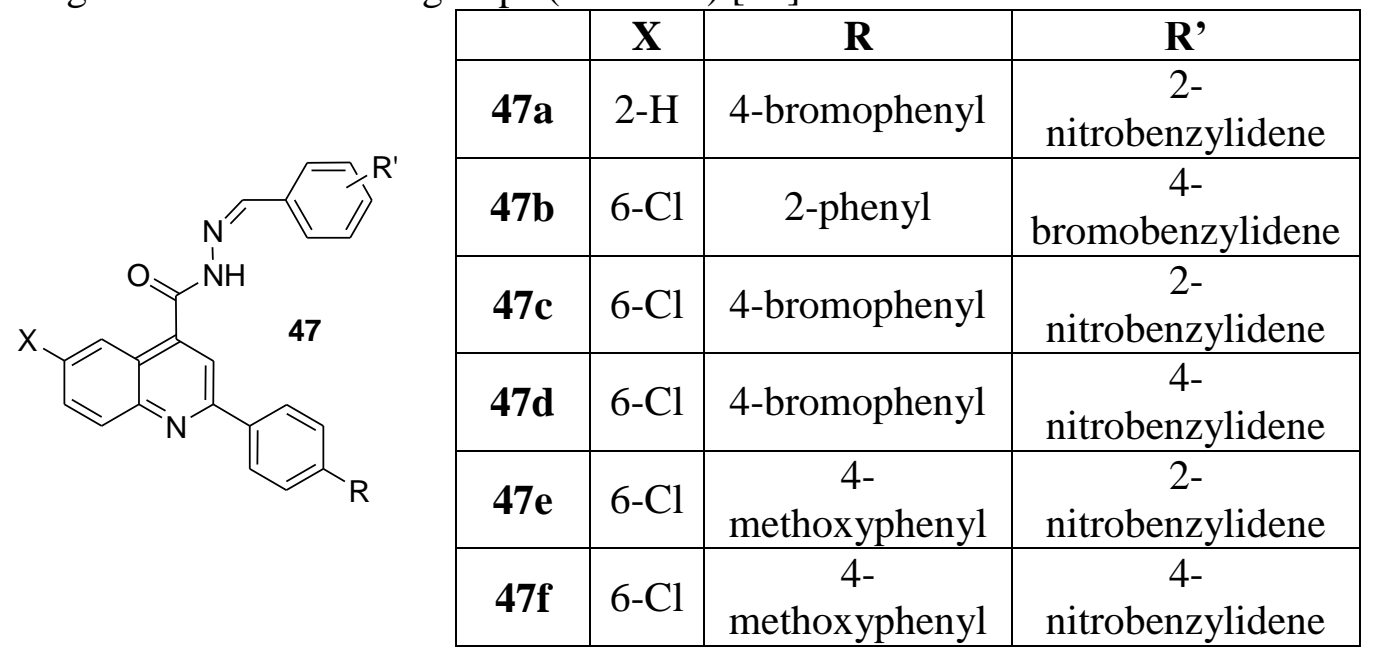

Table 14. Structures of hydrazone derivatives 47.

It has been observed that these compounds presented no activity against Grampositive bacteria such as $S$. aureus (MIC $>200 \mu \mathrm{g} / \mathrm{mL}$ ), while MICs are ranging from 25 to $50 \mu \mathrm{g} / \mathrm{mL}$ against $E$. coli and $C$. albicans (Table 15). These activities against $E$. coli and $C$. albicans are as same as reference drugs. It may also point out that these molecules do not present any haemolytic activity. The authors concluded that the nature of the substituents and substitution pattern on the quinoline ring may have a considerable impact on the observed antibacterial and antifungal activities of the considered hydrazones, para substitution appearing to be more beneficial for activity compared to the ortho one (Table 15). As an improvement of such studies, Shruthi et al. have recently reported that such compounds were found to be active against bacterial strains including Acinetobacter baumannii, Escherichia coli and Staphylococcus aureus.[35]

\begin{tabular}{|c|c|c|}
\cline { 2 - 3 } \multicolumn{1}{c|}{} & \multicolumn{2}{c|}{ MIC $(\mu \mathrm{g} / \mathrm{mL})$} \\
\cline { 2 - 3 } \multicolumn{1}{c|}{ 47a } & $25-50$ & C. albicans \\
\hline 47b & 100 & $25-50$ \\
\hline 47c & $25-50$ & $50-50$ \\
\hline 47d & $25-50$ & 50 \\
\hline
\end{tabular}




\begin{tabular}{|c|c|c|}
\hline $\mathbf{4 7 e}$ & $25-50$ & $25-50$ \\
\hline $\mathbf{4 7 f}$ & $25-50$ & 25 \\
\hline
\end{tabular}

Table 15. Antibacterial activities of hydrazone derivatives 47

Some other compounds 48-50 demonstrated antifungal activities (Table 16). Particularly, compounds 48a and 48d possess a MIC of $128 \mu \mathrm{g} / \mathrm{mL}$ against three different Candida strains.[45-47]<smiles>[R]c1ccc(/C=N/NC(=O)Cn2c(=O)oc3ccccc32)cc1</smiles>

\begin{tabular}{|c|c|c|c|c|c|}
\hline & \multicolumn{5}{|c|}{ MIC $(\mu \mathrm{g} / \mathrm{mL})$} \\
\hline & \multicolumn{2}{|c|}{$\mathbf{R}$} & C. albicans & C. Krusei & C. parapsilosis \\
\hline $48 \mathbf{a}$ & \multicolumn{2}{|c|}{$\mathrm{H}$} & 128 & 128 & 128 \\
\hline $48 b$ & \multicolumn{2}{|c|}{$\mathrm{Br}$} & 64 & 256 & 128 \\
\hline $48 c$ & \multicolumn{2}{|c|}{$\mathrm{Cl}$} & 128 & 256 & 256 \\
\hline 48d & \multicolumn{2}{|c|}{$\mathrm{CH}_{3}$} & 128 & 128 & 128 \\
\hline $48 \mathrm{e}$ & \multicolumn{2}{|c|}{$\mathrm{OCH}_{3}$} & 128 & 128 & 512 \\
\hline 49a & $\mathrm{H}$ & $4-\mathrm{NO}_{2}$ & 100 & 100 & 100 \\
\hline $49 b$ & $\mathrm{CH}_{3}$ & $4-\mathrm{NO}_{2}$ & 100 & 100 & 200 \\
\hline $49 c$ & $\mathrm{C}_{2} \mathrm{H}_{5}$ & $4-\mathrm{Cl}$ & 100 & 100 & 200 \\
\hline 49d & $\mathrm{C}_{2} \mathrm{H}_{5}$ & $4-\mathrm{NO}_{2}$ & 100 & 100 & 200 \\
\hline 50a & \multicolumn{2}{|c|}{$\left(\mathrm{CH}_{2}\right)_{3}$} & 365 & - & - \\
\hline $50 b$ & \multicolumn{2}{|c|}{$\left(\mathrm{CH}_{2}\right)_{4}$} & 365 & - & - \\
\hline $50 \mathrm{c}$ & \multicolumn{2}{|c|}{$\left(\mathrm{CH}_{2}\right)_{5}$} & - & - & - \\
\hline
\end{tabular}

Table 16. Antifungal activities of compounds of 48-50.

In 2001, Chornous et al. have synthesized hydrazone derivatives $\mathbf{5 1}$ possessing a hetero-nitrogen-ring but these molecules demonstrated moderate antibacterial activities against $S$. aureus and $E$. coli (Table 17).[48] 


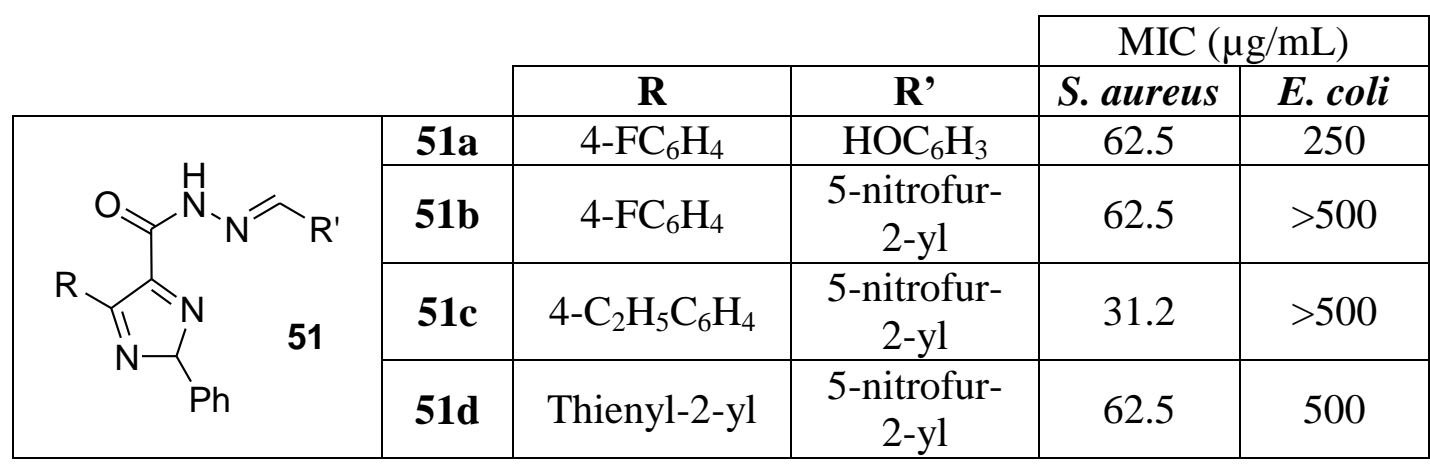

Table 17. Antibacterial activities of compounds 51.

Rahman et al. have also prepared hydrazones bearing long linear alkyl chains terminated by a carboxylic acid or allyl group. All these molecules do not possess any activity against $C$. albicans but are efficient against both Gram-positive and Gram-negative bacteria with diameters of inhibition varying from 10 to $20 \mathrm{~mm}$ (Table 18).[49]<smiles>C=CC(C)(C)CC(=O)N/N=C/c1cccc([N+](=O)[O-])c1</smiles>
52<smiles>[B][13C](C)(C)CC(=O)N/N=C/c1cccc([N+](=O)[O-])c1</smiles><smiles>CC(C)(CSCC(=O)O)CC(=O)N/N=C/c1cccc([N+](=O)[O-])c1</smiles>

\begin{tabular}{|l|c|c|c|c|c|}
\hline & \multicolumn{5}{|c|}{ diameters of inhibition (mm) } \\
\hline & S. aureus & B. subtilis & E. coli & P. aeruginosa & C. albicans \\
\hline $\mathbf{5 2}$ & - & - & 19 & - & - \\
\hline $\mathbf{5 3}$ & 12 & 12 & 10 & 14 & - \\
\hline $\mathbf{5 4}$ & 18 & 15 & 14 & 20 & - \\
\hline
\end{tabular}

Table 18. Antibacterial activities of compounds 52-54.

Another study of interest needs to be mentioned and was reported by Rollas et al. who performed the synthesis of analogues 55a-c possessing nitroaryl or furyl groups. These compounds are very active against Gram-positive $S$. aureus bacteria with MICs ranging from 2 to $8 \mu \mathrm{g} / \mathrm{mL}$ whereas high MICS were encountered against yeasts and Gram-negative bacteria (Table 19).[50] 
<smiles>[13CH3]/C=N/NC(=O)c1ccc(F)cc1</smiles><smiles>Cc1cccc([N+](=O)[O-])c1</smiles>

\begin{tabular}{|c|c|c|c|c|}
\hline & \multicolumn{4}{|c|}{ MIC ( $\boldsymbol{\mu g} / \mathbf{m L})$} \\
\hline & S. aureus & C. albicans & E. coli & P. aeruginosa \\
\hline 55a & 2 & 62.5 & 250 & 250 \\
\hline 55b & 8 & 125 & 125 & 125 \\
\hline $\mathbf{5 5 c}$ & 4 & 125 & 125 & 125 \\
\hline
\end{tabular}

Table 19. Antimicrobial activities of compounds 55a-55c.

In the same area of research, Rao[51], Kursun[52] and Fahmy[53] have performed the synthesis of various analogues of derivatives 56a-d demonstrating also moderate to good antibacterial and antifungal activities against Gram-positive bacteria and fungi with diameter of inhibition ranging from 0 to $17 \mathrm{~mm}$ depending on the considered microorganisms (Table 20).<smiles>COc1ccc(C)cc1</smiles>

Diameter of inhibition ( $\mathrm{mm}$ )

\begin{tabular}{|c|c|c|c|c|c|}
\cline { 2 - 6 } \multicolumn{1}{c|}{} & \multicolumn{5}{c|}{ Diameter of inhibition $(\mathbf{m m})$} \\
\cline { 2 - 6 } \multicolumn{1}{c|}{} & B. subtilis & S. aureus & P. notatum & A. niger & C. utilis \\
\hline $\mathbf{5 6 a}$ & $8^{*}$ & $7^{*}$ & 0 & 0 & 0 \\
\hline $\mathbf{5 6 b}$ & 0 & 0 & $10^{*}$ & 0 & $12^{*}$ \\
\hline $\mathbf{5 6 c}$ & $11^{*}$ & $11^{* *}$ & $12^{*}$ & $16^{*}$ & $17^{*}$ \\
\hline $\mathbf{5 6 d}$ & 10 & 9 & 9 & 14 & 13 \\
\hline
\end{tabular}

*significant **highly significant

Table 20. Antimicrobial activities of compounds 56a-d.

In 2007, numerous parent derivatives such as 57a-c, 58 and 59 have been prepared presenting interesting antibacterial activities against a large panel of bacteria (Scheme 12).[54] 
<smiles>[R]c1ccc(C(=O)N/N=C/c2ccc([N+](=O)[O-])s2)cc1[R]</smiles>

\begin{tabular}{l|l|l} 
& \multicolumn{1}{|c|}{$\mathrm{R}_{1}$} & $\mathrm{R}_{2}$ \\
\hline $\mathbf{5 7 a}$ & $\mathrm{Cl}$ & $\mathrm{Cl}$ \\
$\mathbf{5 7 b}$ & $\mathrm{Br}$ & $\mathrm{H}$ \\
$\mathbf{5 7 c}$ & $\mathrm{COCH}_{3}$ & $\mathrm{H}$ \\
& \multicolumn{2}{|c}{} \\
$\mathbf{5 8}$ & 5-nitro-2-furyl
\end{tabular}<smiles>[R7]C=NNC(=O)c1cc(-c2ccc(F)cc2F)ccc1O</smiles><smiles>Cc1c(/C(=N\NC(N)=O)c2ccccc2)nnc2c3c(-c4ccccc4)c(-c4ccccc4)nnc3nn12</smiles>

Scheme 12

It is noteworthy that 57c possesses the best MICS of 0.11 and $1.27 \mu \mathrm{g} / \mathrm{mL}$ against two different strains of $S$. aureus, respectively. Otherwise, the derivative $\mathbf{5 8}$ presents moderate activities against B. subtilis $(75 \mu \mathrm{g} / \mathrm{mL})$, S. epidermis $(18.75$ $\mu \mathrm{g} / \mathrm{mL})$, E. coli $(75 \mu \mathrm{g} / \mathrm{mL})$ and $S$. aureus $(37.5 \mu \mathrm{g} / \mathrm{mL})$ whereas hydrazone 59 presents a weak activity against all these pathogens.[55] Furthermore, 58 inhibits the growth of $M$. tuberculosis by $34 \%$ at a concentration of $6.25 \mu \mathrm{g} / \mathrm{mL}$.

In 2007, Joshi et al. reported the synthesis of N'-(arylidene)-4-(1H-pyrrol-1-yl) benzohydrazide 60-61 and their moderate to good antimicrobial activities typically against $\mathrm{M}$. tuverculosis with some derivatives $\mathbf{6 1 b}$ and 61e possessing MICs of $32.5 \mu \mathrm{g} / \mathrm{mL}$ (Table 21).[56]<smiles>[R]C([R])=NNC(=O)c1ccc(-n2cccc2)cc1</smiles>

60

\begin{tabular}{l|l|l} 
& $\mathbf{R}$ & $\mathbf{R}_{\mathbf{1}}$ \\
\hline $\mathbf{6 0 a}$ & $\mathrm{CH}_{3}$ & $\mathrm{CH}_{3}$ \\
$\mathbf{6 0 b}$ & $\mathrm{CH}_{3}$ & $\mathrm{C}_{6} \mathrm{H}_{5}$ \\
$\mathbf{6 0 c}$ & $\mathrm{C}_{6} \mathrm{H}_{5}$ & $\mathrm{C}_{6} \mathrm{H}_{5}$
\end{tabular}<smiles>[R]C=NNC(C)=O</smiles>

61<smiles>c1ccc(-n2cccc2)cc1</smiles>
61c<smiles>[R][K]</smiles><smiles>Cc1cccc([N+](=O)[O-])c1</smiles>

$61 \mathrm{e}$<smiles>Cc1ccc(N(C)C)cc1</smiles>

\begin{tabular}{|c|c|c|c|c|c|c|}
\cline { 2 - 7 } \multicolumn{1}{c|}{} & \multicolumn{6}{c|}{$\mathrm{MIC}(\mu \mathrm{g} / \mathrm{mL})$} \\
\cline { 2 - 7 } \multicolumn{1}{c|}{} & $\begin{array}{c}\text { S. } \\
\text { aureus }\end{array}$ & $\begin{array}{c}\boldsymbol{E} . \\
\text { faecalis }\end{array}$ & $\begin{array}{c}\text { M. } \\
\text { tuberculosis }\end{array}$ & $\begin{array}{c}\boldsymbol{K} . \\
\text { pneumoniae }\end{array}$ & $\begin{array}{c}\boldsymbol{E} . \\
\text { coli }\end{array}$ & $\begin{array}{c}\boldsymbol{P} . \\
\text { aeruginosa }\end{array}$ \\
\hline 60a & 250 & 125 & 62.5 & 250 & 125 & 62.5 \\
\hline $60 \mathrm{~b}$ & 250 & 125 & 62.5 & 125 & 125 & 62.5 \\
\hline
\end{tabular}




\begin{tabular}{|c|c|c|c|c|c|c|}
\hline 60c & 500 & 250 & 62.5 & 125 & 125 & 62.5 \\
\hline 61a & 250 & 250 & 125 & 125 & 125 & 125 \\
\hline 61b & 125 & 125 & 31.25 & 125 & 62.5 & 62.5 \\
\hline 61c & 500 & 500 & 62.5 & 500 & 500 & 62.5 \\
\hline 61d & 250 & 125 & 62.5 & 125 & 250 & 125 \\
\hline 61e & 125 & 125 & 31.25 & 125 & 62.5 & 62.5 \\
\hline
\end{tabular}

Table 21. Antibacterial activities of compounds 60-61

The design of derivatives $\mathbf{6 2}$ and $\mathbf{6 3}$ led to products active against M. tuberculosis with MICs varying from 0.39 to $15 \mu \mathrm{M}, \mathbf{6 3 b}$ being the most active compound of this series (Scheme 13).[57]<smiles>[R]/C=N\NC(=O)CSc1nnc(-c2ccco2)n1CC</smiles>

\section{Scheme 13}

Recently, Muluk et al. reported the synthesis of new pyridyl and thiazolyl clubbed hydrazone derivatives 64 displaying moderate antimicrobial activities and suggesting that the design of new parent derivatives could improve the selectivity and activity encountered (Table 22).[58]

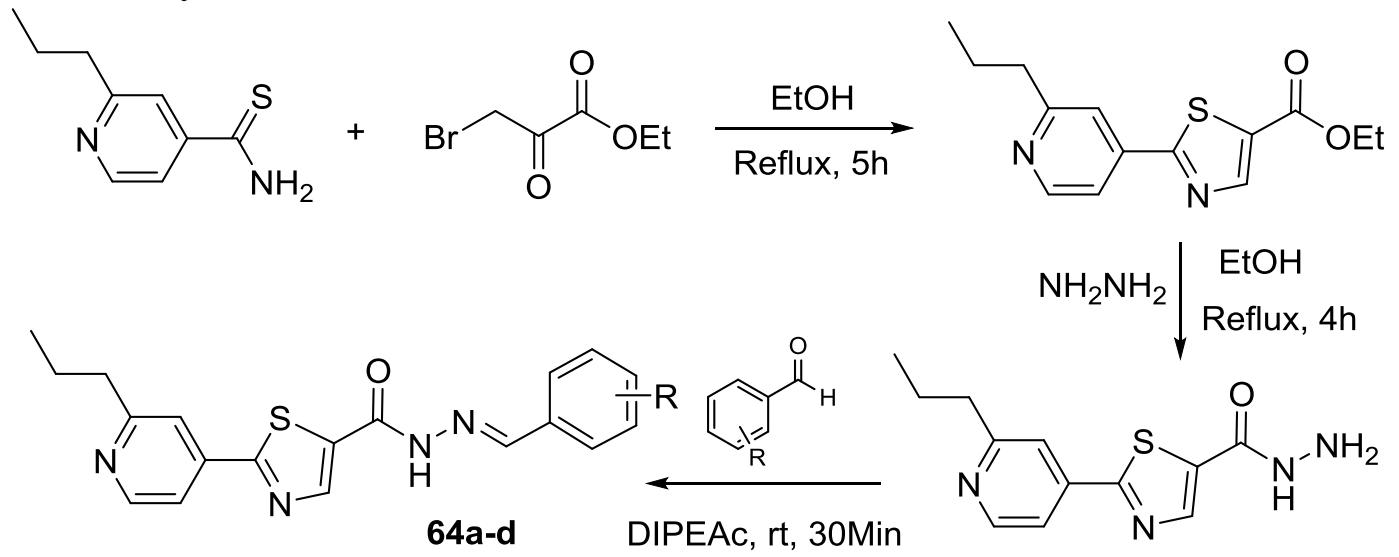

\begin{tabular}{|c|c|c|c|c|}
\hline & & \multicolumn{3}{|c|}{$\mathrm{MIC}(\mu \mathrm{g} / \mathrm{mL})$} \\
\hline & $\mathbf{R}$ & B. subtilis & E. aerogenes & C. albicans \\
\hline $\mathbf{6 4 a}$ & $3,5-\mathrm{Cl}$ & 90 & 170 & 150 \\
\hline $\mathbf{6 4 b}$ & $4-\mathrm{Cl}$ & 260 & 120 & 280 \\
\hline $\mathbf{6 4 c}$ & $3-\mathrm{Cl}$ & 120 & 150 & 250 \\
\hline
\end{tabular}




\begin{tabular}{|c|c|c|c|c|}
\hline 64d & $2-\mathrm{NO}_{2}$ & 75 & 85 & 210 \\
\hline Streptomycin & - & 25 & 30 & NA \\
\hline Fluconazole & - & NA & NA & 30 \\
\hline
\end{tabular}

Table 22. Structure and antimicrobial activities of compounds 64a-64d.

To further dissect the structural features necessary to inhibit azole-resistant fungal species, Backes et al. have recently performed the synthesis of a new class of modified salicylaldehyde derivatives and subsequently identified a series of modified pyridine-based hydrazones 65a-f possesing fungicidal and antifungal activities against numerous Candida spp (Table 23).[59]

\begin{tabular}{|c|c|c|c|c|}
\hline \\
\hline
\end{tabular}

Table 23. Structure and antimicrobial activities of compounds 65a-65f.

Condensation of 5,6,7,8-tetrahydroimidazo[1,2-a]-pyrimidine-2-carbohydrazide with various aromatic aldehydes in ethanol at reflux led to the generation of hydrazone derivatives 66 in 80-92\% yield. Compounds 66d, 66e and 66f exhibited excellent antibacterial activity with zone of inhibition $30-33 \mathrm{~mm}$ against $E$. coli and $S$. aureus. These compounds also exhibited excellent antibacterial activity with zone of inhibition ranging from 22 to $25 \mathrm{~mm}$ against $P$. aeruginosa and $S$. pyogenes (Table 24).[60] 


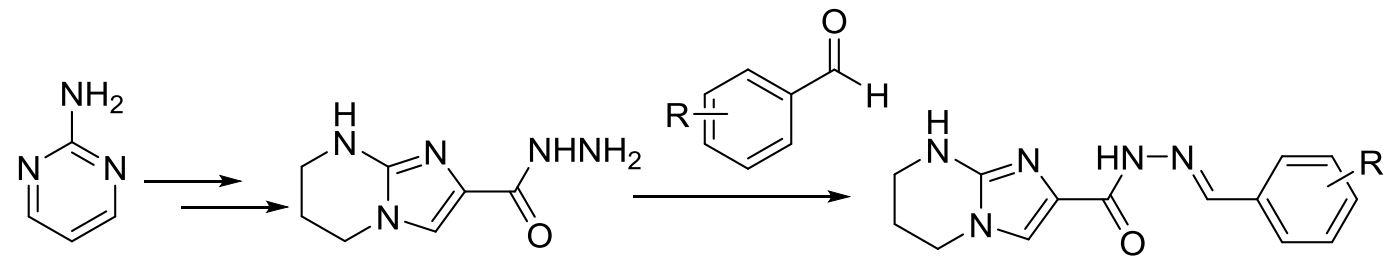

66a-h

\begin{tabular}{|c|c|c|c|c|c|}
\hline & \multirow[b]{2}{*}{$\mathbf{R}$} & \multicolumn{4}{|c|}{$\begin{array}{l}\text { Zone of inhibition of compounds 66a-f } \\
\text { Concentration used } 250 \mu \mathrm{g} / \mathrm{mL} \text { of DMSO }\end{array}$} \\
\hline & & $\begin{array}{c}\text { E. coli } \\
\text { MTCCC443 }\end{array}$ & $\begin{array}{l}\text { P. aeruginosa } \\
\text { MTCC } 424\end{array}$ & $\begin{array}{l}\text { S. aureus } \\
\text { MTCC96 }\end{array}$ & $\begin{array}{l}\text { S. pyogenes } \\
\text { MTCC } 442\end{array}$ \\
\hline $66 a$ & $4-\mathrm{F}$ & 25 & 19 & 24 & 17 \\
\hline $66 \mathrm{~b}$ & $2-\mathrm{CF}_{3}$ & 27 & 20 & 23 & 18 \\
\hline $66 \mathrm{c}$ & $3-\mathrm{CF}_{3}$ & 26 & 19 & 23 & 17 \\
\hline 66d & $4-\mathrm{CF}_{3}$ & 33 & 24 & 29 & 24 \\
\hline $66 \mathrm{e}$ & $4-\mathrm{OCF}_{3}$ & 30 & 25 & 30 & 22 \\
\hline $66 f$ & $4-\mathrm{OCHF}_{2}$ & 30 & 23 & 31 & 22 \\
\hline $66 \mathrm{~g}$ & $2,4-\mathrm{F}$ & 20 & 16 & 19 & 13 \\
\hline $66 \mathrm{~h}$ & $3,4-\mathrm{F}$ & 21 & 15 & 19 & 14 \\
\hline
\end{tabular}

Table 24. Structure and antimicrobial activities of compounds 66a-66h.

In another work, the synthesis of imidazole hydrazone derivatives 67a-m and their evaluation against $A$. niger, $S$. aureus, S. pyogenes, E. coli and $P$. aeruginosa resulted in moderate to good antimicrobial activities (Table 25).[61]

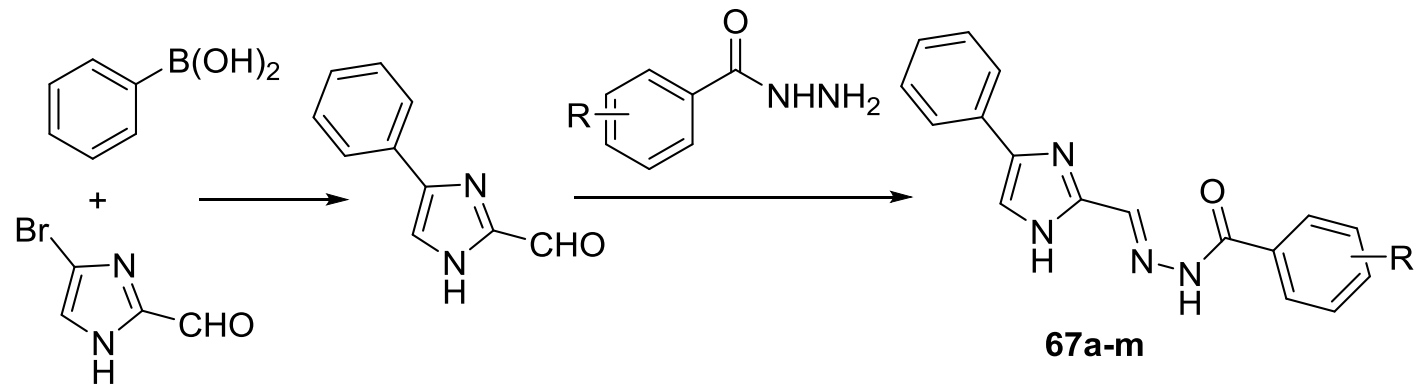

\begin{tabular}{|c|c|c|c|c|c|c|}
\hline & & \multicolumn{5}{|c|}{$\begin{array}{l}\text { Zone of inhibition of compounds 67a-m } \\
\text { Concentration used } 250 \mu \mathrm{g} / \mathrm{mL} \text { of DMSO }\end{array}$} \\
\hline & $\mathbf{R}$ & $\begin{array}{c}\text { E. coli } \\
\text { MTCCC443 }\end{array}$ & $\begin{array}{l}\text { P. aeruginosa } \\
\text { MTCC424 }\end{array}$ & $\begin{array}{l}\text { S. aureus } \\
\text { MTCC96 }\end{array}$ & $\begin{array}{l}\text { S. pyogenes } \\
\text { MTCC442 }\end{array}$ & $\begin{array}{l}\text { A. niger } \\
\text { MTCC282 }\end{array}$ \\
\hline $67 a$ & $\mathrm{H}$ & 26 & 24 & 18 & 17 & 26 \\
\hline $67 b$ & 4-OH & 28 & 27 & 24 & 25 & 30 \\
\hline
\end{tabular}




\begin{tabular}{|c|c|c|c|c|c|c|}
\hline $\mathbf{6 7 c}$ & $4-\mathrm{Br}$ & 15 & 13 & - & - & 22 \\
\hline $\mathbf{6 7 d}$ & $4-\mathrm{Cl}$ & 14 & 12 & - & - & 21 \\
\hline $\mathbf{6 7 e}$ & $4-\mathrm{F}$ & 25 & 23 & 25 & 23 & 28 \\
\hline $\mathbf{6 7 f}$ & $4-\mathrm{SO}_{2} \mathrm{CH}_{3}$ & 30 & 30 & 26 & 25 & 31 \\
\hline $\mathbf{6 7 g}$ & $3-\mathrm{NO}_{2}$ & 25 & 24 & 18 & 19 & 28 \\
\hline $\mathbf{6 7 h}$ & $3-\mathrm{Cl}$ & 14 & 12 & - & - & 21 \\
\hline $\mathbf{6 7 i}$ & $2-\mathrm{Br}$ & 13 & 13 & - & - & 20 \\
\hline $\mathbf{6 7 j}$ & $2-\mathrm{I}$ & 15 & 14 & - & - & 18 \\
\hline $\mathbf{6 7 k}$ & $2,5-\mathrm{F}$ & 28 & 27 & 20 & 20 & 30 \\
\hline $\mathbf{6 7 1}$ & $3,5-\mathrm{Cl}$ & 15 & 15 & - & - & 17 \\
\hline $\mathbf{6 7 m}$ & $2,4-\mathrm{Cl}$ & 14 & 13 & - & - & 16 \\
\hline
\end{tabular}

Table 25. Structure and antimicrobial activities of compounds 67a-m.

Pilai et al. have recently described the steroselective synthesis of a series of novel cyanoacetyl hydrazones of 3-alkyl-2,6-diarylpiperidin-4-ones 68a-j demonstrating interesting antibacterial activities against E. aerogenes and some fungal strains (Table 26).[62]

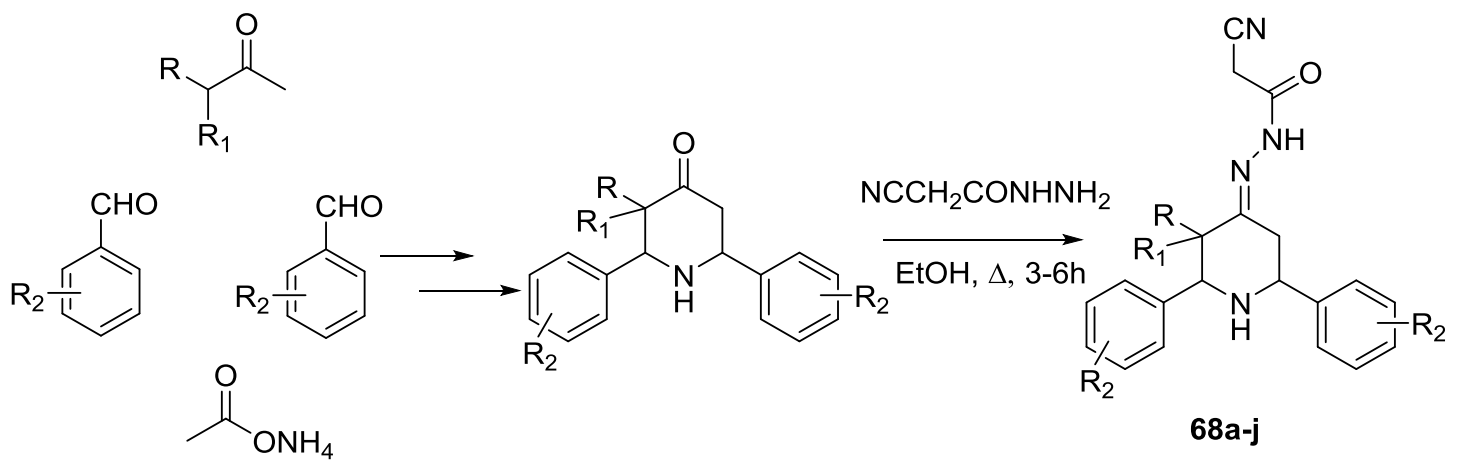

\begin{tabular}{|c|c|c|c|c|c|}
\hline & & \multicolumn{5}{|c|}{$\begin{array}{c}\text { Zone of inhibition of compounds 68a-j } \\
\text { Concentration used 250 } \mathbf{\mu g} / \mathbf{m L} \text { of DMSO }\end{array}$} \\
\hline & $\mathbf{R} / \mathbf{R}_{\mathbf{1}} / \mathbf{R}_{\mathbf{2}}$ & E. coli & E. aerogenes & S. aureus & C. albicans \\
\hline $\mathbf{6 8 a}$ & $\mathrm{Me} / \mathrm{H} / \mathrm{H}$ & - & 34 & - & 9 \\
\hline $\mathbf{6 8 b}$ & $\mathrm{Et} / \mathrm{H} / \mathrm{H}$ & - & - & - & 6 \\
\hline $\mathbf{6 8 c}$ & $\mathrm{Me} / \mathrm{Me} / \mathrm{H}$ & - & 14 & - & 19 \\
\hline $\mathbf{6 8 d}$ & $\mathrm{Me} / \mathrm{H} / p-\mathrm{Me}$ & 11 & 11 & 12 & - \\
\hline $\mathbf{6 8 e}$ & $\mathrm{Me} / \mathrm{H} / p-\mathrm{OMe}$ & 9 & 12 & - & 12 \\
\hline $\mathbf{6 8 f}$ & $\mathrm{Me} / \mathrm{H} / o-\mathrm{Cl}$ & 12 & 9 & - & - \\
\hline $\mathbf{6 8 g}$ & $\mathrm{Me} / \mathrm{H} / m-\mathrm{NO}{ }_{2}$ & 14 & 11 & - & 12 \\
\hline $\mathbf{6 8 h}$ & $\mathrm{Me} / \mathrm{H} / p-\mathrm{F}$ & - & - & 16 & 8 \\
\hline $\mathbf{6 8 i}$ & $\mathrm{Me} / \mathrm{H} / p-\mathrm{Cl}$ & - & - & - & 7 \\
\hline
\end{tabular}




\begin{tabular}{|l|l|l|l|l|l|}
\hline $\mathbf{6 8 j}$ & $\mathrm{Me} / \mathrm{H} / p$ - $\mathrm{Br}$ & - & $\ldots$ & 16 & 28 \\
\hline
\end{tabular}

Table 26. Structure and antimicrobial activities of compounds $68 \mathbf{a}-\mathbf{j}$

Another example to be cited deals with the synthesis of hydrazone derivatives of anacardic acid linked with 1,2,3-triazole ring and exhibiting strong antifungal activity against $A$. niger and $C$. albicans (Table 27).[63]

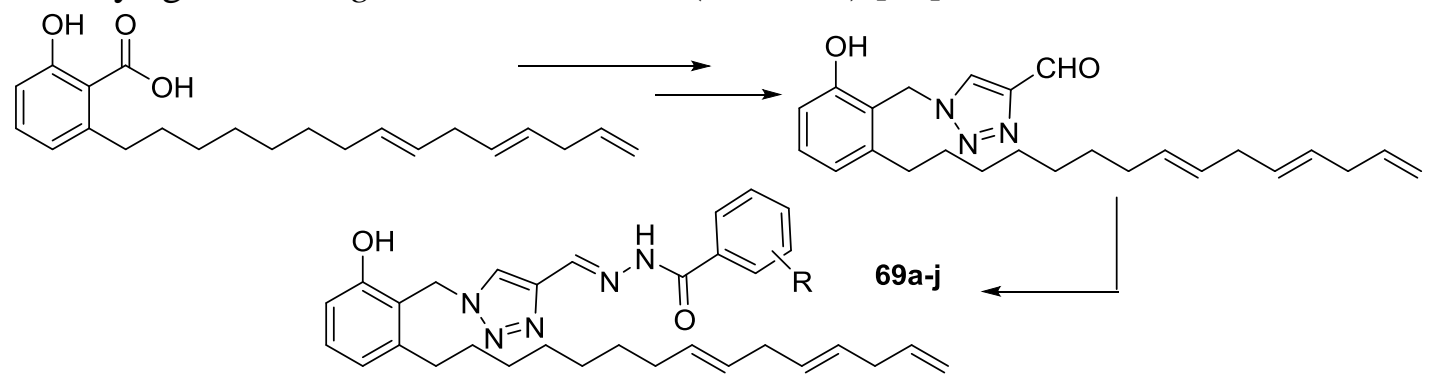

\begin{tabular}{|c|c|c|c|}
\hline & & \multicolumn{2}{|c|}{$\begin{array}{c}\text { Zone of inhibition of compounds 69a-j } \\
\text { Concentration used } \mathbf{2 5 0} \boldsymbol{\mu g} / \mathbf{m L} \text { of DMSO }\end{array}$} \\
\hline & $\mathbf{R}$ & A. niger & C. albicans \\
\hline 69a & $\mathrm{H}$ & 16 & 15 \\
\hline 69b & $4-\mathrm{OMe}$ & 13 & 12 \\
\hline 69c & $4-\mathrm{Cl}$ & 17 & 18 \\
\hline 69d & $4-\mathrm{OH}$ & 26 & 23 \\
\hline 69e & $3,4,5-\mathrm{OMe}$ & 27 & 24 \\
\hline $\mathbf{6 9 f}$ & $2,5-\mathrm{Cl}$ & 19 & 19 \\
\hline $\mathbf{6 9 g}$ & $3,5-\mathrm{Cl}$ & 20 & 20 \\
\hline $\mathbf{6 9 h}$ & $\mathrm{Me} / \mathrm{H} / m-\mathrm{NO}_{2}$ & 25 & 24 \\
\hline $\mathbf{6 9} \mathbf{i}$ & $4-\mathrm{F}$ & 24 & 22 \\
\hline $\mathbf{6 9} \mathbf{j}$ & $2,5-\mathrm{F}$ & 26 & 24 \\
\hline
\end{tabular}

Table 27. Structure and antimicrobial activities of compounds $69 \mathbf{a}-\mathbf{j}$

\section{CONCLUDING REMARKS}

Numerous different approaches have been depicted for the design and synthesis of hydrazones presenting interesting antimicrobial activities. It also remains clear that this class of compounds is still too neglected as outlined in a previous review highlighting their use as metal ligands for the formation of hydrazone-transition metal complexes possessing interesting biological, analytical and catalytic applications.[64] 


\section{CONFLICT OF INTEREST}

None declare

\section{ACKNOWLEDGEMENT}

None declare

\section{REFERENCES}

1. Chaudhary T, Varshney S, Singh A. An updated review on biological activities of hydrazone derivatives. World J Pharm Pharm Sci. 2018;7(10):153269.

2. Narang R, Narasimhan B, Sharma S. A review on biological activities and chemical synthesis of hydrazide derivatives. Curr Med Chem. 2012;19(4):569612.

3. Negi VJ, Sharma AK, Negi JS, Ram V. Biological activities of hydrazone derivatives in the new millennium. Int J Pharm Chem. 2012;2(4):100-9.

4. Popiolek L. Hydrazide-hydrazones as potential antimicrobial agents: overview of the literature since 2010. Med Chem Res. 2017;26(2):287-301.

5. Sayed AR, Ali SH, Gomha SM, Al-Faiyz YS. Review of the synthesis and biological activity of hydrazonoyl halides. Synth Commun. 2020;50(21):3175203.

6. Omidi S, Kakanejadifard A. A review on biological activities of Schiff base, hydrazone, and oxime derivatives of curcumin. RSC Adv. 2020;10(50):30186-202.

7. de Oliveira Carneiro Brum J, Costa Franca TC, LaPlante SR, Figueroa Villar JD. Synthesis and Biological Activity of Hydrazones and Derivatives: A Review. Mini-Rev Med Chem. 2020;20(5):342-68.

8. Bamford WR, Stevens TS. The decomposition of toluene-psulphonylhydrazones by alkali. J Chen Soc. 1952;55:4735-40.

9. Shapiro RH, Lipton MF, Kolondo KJ, Buswell RL, Capuano LA. Tosylhydrazones and alkyllithium reagents: More on the regiospecificity of the reaction and the trapping of three intermediates. Tetrahedron Lett 1975;22:18114.

10. Rollas S, Kuçükgüzel SG. Biological activities of hydrazone derivatives. Molecuels. 2007;12:1910-39.

11. Shinge PS, Mallur SG, Badami BV. Termolecular one-pot synthesis of symmetrical azines of 4-acetyl-3-arylsydnones. Hydrazone and azine derivatives of 4-acetyl-3-arylsydnones, their spectral characterization and biological properties. J Indian Chem Soc. 2005;82(7):659-64.

12. Sztanke K, Pasternak K, Rzymowska J, Sztanke M, Kandefer-Szerszen M, Dybala I, et al. Identification of antitumour activity of novel derivatives of 8-aryl- 
2,6,7,8-tetrahydroimidazo[2,1-c][1,2,4]triazine-3,4-dione and 8-aryl-4-imino2,3,7,8-tetrahydroimidazo[2,1-c][1,2,4]triazin-3(6H)-one. Bioorg Med Chem. 2007;37(8):2837-49.

13. Moreau S, Varache-Lembège M, Larrouture S, Fall D, Neveu A, Deffieux $\mathrm{G}$, et al. (2-Arylhydrazonomethyl)-substituted xanthones as antimycotics: synthesis and fungistatic activity against Candida species. Eur J Med Chem 2002;37:237-53.

14. Tyrkov AG, Sukhenko LT. Synthesis and antimicrobial activity of substituted nitro-1,2,4-oxadiazole-5-carbaldehyde hydrazones. Pharm Chem J. 2004;38(7):376-8.

15. Dimmock JR, Kirkpatrick DL, Negrave LE, Russell KL, Pannekoek WJ. Preparation of some hydrazones of conjugated styryl ketones and related compounds for evaluation principally as antineoplastic agents. Can J Pharm Sci. 1981;16(1):1-7.

16. Gein VL, Gein LF, Chirkova MV, Mikhalev VA, Voronina EV. Synthesis, properties, and antimicrobial activity of 3-hydrazones of 1-aryl-5-methyl-1,5ethoxycarbonylpyrrolidine-2,3-diones. Pharm Chem J. 2005;39(8):413-7.

17. Nayyar A, Malde A, Coutinho E, Jain R. Synthesis, anti-tuberculosis activity, and 3D-QSAR study of ring-substituted-2/4-quinolinecarbaldehyde derivatives. Bioorg Med Chem 2006;14:7302-10.

18. Oliveira CGT, Miranda FF, Ferreira VF, Freitas CC, Rabello RF, Carballido JM, et al. Synthesis and antimicrobial evaluation of 3-hydrazinonaphthoquinones as analogs of lapachol. J Braz Chem Soc. 2001;12(3):339-45.

19. El-Bendary ER, Goda FE, Maarouf AR, Badria FA. Synthesis and antimicrobial evaluation of 3-hydrazino-quinoxaline derivatives and their cyclic analogues. Sci Pharm. 2004;72(2):175-85.

20. Savini L, Chiasserini L, Travagli V, Pellerano C, Novellino E, Cosentino $\mathrm{S}$, et al. New a-(N)-heterocyclic hydrazones: evaluation of anticancer, anti-HIV and antimicrobial activity. Eur J Med Chem. 2004;39(2):113-22.

21. Küçükgüzel ŞG, S. R, H. E, M. K. Synthesis, characterization and antimicrobial evaluation of ethyl 2-arylhydrazono-3-oxobutyrates. Eur J Med Chem. 1999;34:153-60.

22. Turan-Zitoun G, Saglik BN, Cevik UA, Levent S, Ilgin S, Hussein W. Synthesis and antimicrobial activity of new 2-((1-furan-2yl)ethylidene)hydrazono)-4-phenylthiazol-3(2H)-amine derivatives and their schiff bases with 4-nitrobenzaldehyde. Phosphorus, Sulfur Silicon Relat Elem. 2018;193(11):744-51.

23. Shaban MAE, Nasr AZ, Morgaan AE. Sterically controlled regiospecific heterocyclization of 3-hydrazino-5-methyl-1,2,4-triazino[5,6-b]indole to 10methyl-1,2,4-triazolo[4',3':2,3]1,2,4-triazino[5,6-b]indoles. Il Farmaco 1999;54:800-9. 
24. El-Gazzar A-RBA, El-Enany MM, Mahnoud MN. Synthesis, analgesic, anti-inflammatory, and antimicrobial activity of some novel pyrimido[4,5b]quinolin-4-ones. Bioorg Med Chem 2008;16,:3261-73.

25. Nassar IF, Farargy AFE, Abdelrazek FM, Hamza Z. Synthesis of new uracil derivatives and their sugar hydrazones with potent antimicrobial, antioxidant and anticancer activities. Nucleosides, Nucleotides Nucleic Acids. 2020:Ahead of Print.

26. Dewangan D, Nakhate K, Mishra A, Thakur AS, Rajak H, Dwivedi J, et al. Design, Synthesis, and Characterization of Quinoxaline Derivatives as a Potent Antimicrobial Agent. J Heterocycl Chem. 2019;56(2):566-78.

27. Faidallah HM, Khan KA, Asiri AM. Synthesis and characterization of a novel series of benzenesulfonyl urea and thiourea derivatives of $2 \mathrm{H}$-pyran and $2 \mathrm{H}$-pyridine-2-ones as antibacterial, antimycobacterial and antifungal agents. Eur J Chem. 2011;2(2):243-50.

28. Koca M, Ahmedzade M, Cukurovali A, Kazaz C. Studies on the synthesis and reactivity of novel benzofuran-2-yl-[3-methyl-3-phenylcyclobutyl] methanones and their antimicrobial activity. Molecules. 2005;10(7):747-54.

29. Khan SA, Saleeem K, Khan Z. Synthesis, structure elucidation and antibacterial evaluation of new steroidal -5-en-7-thiazoloquinoxaline derivatives. Eur J Med Chem 2007;43(10):2257-61.

30. Khan SA, Kumar PP, Joshi R, Iqbal PF, Saleem K. Synthesis and in vitro antibacterial activity of new steroidal thiosemicarbazone derivatives. Eur J Med Chem. 2008;43(9):2029-34.

31. Karali N, Gûrsoy A, Kandemirli F, Shvets N, Kaynak B, Özbey V, et al. Synthesis and structure-antituberculosis activity relationship of 1H-indole-2,3dione derivatives. Bioorg Med Chem 2007;15:5888-904.

32. Küçükgüzel I, Tatar E, Küçükgüzel ŞG, S. R, De Clercq E. Synthesis of some novel thiourea derivatives obtained from 5-[(4-aminophenoxy)methyl]-4alkyl/aryl-2,4-dihydro-3H-1,2,4-triazole-3-thiones and evaluation as antiviral/antiHIV and anti-tuberculosis agents. Eur J Med Chem. 2007;43:381-92.

33. Yurttas L, Ozkay Y, Kaplancikli ZA, Tunali Y, Karaca H. Synthesis and antimicrobial activity of some new hydrazone-bridged thiazole-pyrrole derivatives. J Enzyme Inhib Med Chem. 2013;28(4):830-5.

34. Abass M, Othman ES. Substituted quinolinones. Part 22. In vitro antimicrobial evaluation of some 4-hydroxy-1-methyl-3-pyrazolinylquinolin$2(1 \mathrm{H})$-ones as useful antibiotic intermediates. Res Chem Intermed. 2015;41(1):117-25.

35. Shruthi TG, Subramanian S, Eswaran S. Design, synthesis and study of antibacterial and antitubercular activity of quinoline hydrazone hybrids. Heterocycl Commun. 2020;26(1):137-47.

36. Al-Rasheed HH, Al Alshaikh M, Khaled JM, Alharbi NS, El-Faham A. Ultrasonic irradiation: synthesis, characterization, and preliminary antimicrobial 
activity of novel series of 4,6-disubstituted-1,3,5-triazine containing hydrazone derivatives. J Chem. 2016:3464758/1-/9.

37. Kaur AP, Gautam D. Ultrasound aided expedient synthesis, characterization and antimicrobial studies of fluorenyl-hydrazono-thiazole derivatives. Asian J Chem. 2019;31(10):2245-8.

38. Deshineni R, Velpula R, Koppu S, Pilli J, Chellamella G. One-pot multicomponent synthesis of novel ethyl-2-(3-((2-(4-(4-aryl)thiazol-2yl)hydrazono)methyl)-4-hydroxy/isobutoxyphenyl)-4-methylthiazole-5-

carboxylate derivatives and evaluation of their in vitro antimicrobial activity. $J$ Heterocycl Chem. 2020;57(3):1361-7.

39. Bhatt DJ, Kamdar GC, Parikh AR. Studies on sulfonylhydrazones: preparation and antimicrobial activity of arylsulfonyl-(4-substituted)aceto/propiophenone hydrazones. J Indian Chem Soc. 1984;61(9):788-9.

40. Salama MA, Farrag HA. Some new naphthalenesulfonyl hydrazones and their antimicrobial activity. Egypt J Pharm Sci. 1995;36(1-6):407-13.

41. Shad RR, Shad VH, Parikh AR. Studies or arylsulfonyl hydrazones : preparation and antimicrobial activity of arylsulfonyl-(2,5-dihydroxy-3-bromo)aceto/enzophenone hydrazones. Ind J Pharm Sci. 1993;55:204-6.

42. Loncle C, Brunel JM, Vidal N, Dherbomez M, Letourneux Y. Synthesis and antifungal activity of cholesterol-hydrazone derivatives. Eur J Med Chem. 2004;39:1067-71.

43. Nadaraia NS, Barbakadze NN, Kakhabrishvili ML, Mshvildadze VD. Synthesis and biological activity of hydrazones of $5 \alpha$-steroids. Res J Pharm, Biol Chem Sci. 2019;10(1):238-43.

44. Metwally KA, Abdel-Aziz LM, Lashine E-SM, Husseiny MI, Badawy RH. Hydrazones of 2-aryl-quinoline-4-carboxylic acid hydrazides: Synthesis and preliminary evaluation as antimicrobial agents. Bioorg Med Chem. 2006;14(24):8675-82.

45. Salgin-Göksen U, Gökhan-Kelekçi N, Göktas Ö, Köysal Y, Kiliç E, Isik S, et al. 1-Acylthiosemicarbazides, 1,2,4-triazole-5(4H)-thiones, 1,3,4-thiadiazoles and hydrazones containing 5-methyl-2-benzoxazolinones: synthesis, analgesicanti-inflammatory and antimicrobial activities. Bioorg Med Chem 2007;15:573851.

46. Ersan S, Nacak S, Berkem R. Synthesis and antimicrobial activity of N[(alpha-methyl)benzylidene]-(3-substituted-1,2,4-triazol-5-yl-thio) acetohydrazides. Il Farmaco 1998;53:773-6.

47. Papakonstantinuo-Garoufalias S, Pouli N, Marakos P, Chytyroglou-Ladas A. Synthesis antimicrobial and antifungal activity of some new 3 substituted derivatives of 4-(2,4-dichlorophenyl)-5-adamantyl-1H-1,2,4-triazole. Il Farmaco. 2002;57:973-7.

48. Chornous VA, Bratenko MK, Vovk MV, Sidorchuk II. Synthesis and antimicrobial activity of pyrazole-4-carboxylic acid hydrazides and N-(pyrazol-4- 
ylcarbonyl)hydrazones of aromatic and heteroaromatic aldehydes. Pharm Chem J. 2001;35(4):203-5.

49. Rahman VPM, Mukhtar S, Ansari WH, Lemiere G. Synthesis, stereochemistry and biological activity of some novel long alkyl chain substituted thiazolidin-4-ones and thiazan-4-one from 10-undecenoic acid hydrazide. Eur J Med Chem. 2005;40(2):173-84.

50. Rollas S, Gulerman N, Erdeniz H. Synthesis and antimicrobial activity of some new hydrazones of 4-fluorobenzoic acid hydrazide and 3-acetyl-2,5disubstituted-1,3,4-oxadiazolines. Il Farmaco. 2002;57(2):171-4.

51. Rao NR. Synthesis and antimicrobial evaluation of fluorinated chalcones. Asian J Chem. 2004;16(1):525-7.

52. Kursun Aktar BS, Sicak Y, Tok TT, Oruc-Emre EE, Yaglioglu AS, Iyidogan $\mathrm{AK}$, et al. Designing heterocyclic chalcones, benzoyl/sulfonyl hydrazones: An insight into their biological activities and molecular docking study. J Mol Struct. 2020;1211:128059.

53. Fahmy HH, Kassem EMM, Abdou WAM, Mahmoud SA. Synthesis of some new indole derivatives of possible antimicrobial activity. Egypt J Pharm Sci. 1998;38(1-3):13-22.

54. Masunari A, Tavares LC. A new class of nifuroxazide analogues: synthesis of 5-nitrothiophene derivatives with antimicrobial activity against multidrugresistant Staphylococcus aureus. Bioorg Med Chem. 2007;15:4229-36.

55. Küçükgüzel ŞG, Mazi A, Şahin F, S. Ö, Stables JP. Synthesis and biological activities of diflunisal hydrazide-hydrazones. Eur J Med Chem. 2003;38:1005-13.

56. Joshi SD, Vagdevi HM, Vaidya VP, Gadaginamath GS. Synthesis of new 4-pyrrol-1-yl benzoic acid hydrazide analogs and some derived oxadiazole, triazole and pyrrole ring systems: a novel class of potential antibacterial and antitubercular agents. Eur J Med Chem. 2007;43(9):1989-96.

57. Shiradkar MR, Murahari KK, Gangadasu HR, Suresh T, Kalyan CA, Panchal D, et al. Synthesis of new S-derivatives of clubbed triazolyl thiazole as anti-Mycobacterium tuberculosis agents. Bioorg Med Chem. 2007;15:3997-4008.

58. Muluk MB, Ubale AS, Dhumal ST, Rehman NNMA, Dixit PP, Kharat $\mathrm{KK}$, et al. Synthesis, anticancer and antimicrobial evaluation of new pyridyl and thiazolyl clubbed hydrazone scaffolds. Synth Commun. 2020;50(2):243-55.

59. Backes GL, Jursic BS, Neumann DM. Potent antimicrobial agents against azole-resistant fungi based on pyridinohydrazide and hydrazomethylpyridine structural motifs. Bioorg Med Chem. 2015;23(13):3397-407.

60. Kethireddy S, Eppakayala L, Maringanti TC. Synthesis and antibacterial activity of novel 5,6,7,8-tetrahydroimidazo[1,2-a]pyrimidine-2-carbohydrazide derivatives. Chem Cent J. 2015;9:51/1-/6.

61. Prasanna VL, Narender R. Synthesis and antimicrobial activity of new imidazole-hydrazone derivatives. Asian J Chem. 2015;27(10):3605-8. 
62. Velayutham Pillai M, Rajeswari K, Vidhyasagar T. Stereoselective synthesis, spectral and antimicrobial studies of some cyanoacetyl hydrazones of 3alkyl-2,6-diarylpiperidin-4-ones. J Mol Struct. 2014;1076:174-82.

63. Rambabu N, Dubey PK, Ram B, Balram B. Synthesis, characterization and antimicrobial evaluation of (E)-N'-[(1-(2-methoxy-6-pentadecylbenzyl)-1H-1, 2, 3-triazol-4-yl]- methylene)benzohydrazide derivatives. Asian J Chem. 2016;28(1):175-80.

64. Shakdofa MME, Shtaiwi MH, Morsy N, Abdel-rassel TMA. Metal complexes of hydrazones and their biological, analytical and catalytic applications: A review. Main group Chem. 2014;13(3):187-218. 